\title{
Review
}

\section{Oral Health Disorders in Parkinson's Disease: More than Meets the Eye}

\author{
Manon Auffret ${ }^{\mathrm{a}, \mathrm{b}, *}$, Vincent Meuric ${ }^{\mathrm{c}}$, Emile Boyer $^{\mathrm{c}}$, Martine Bonnaure-Mallet ${ }^{\mathrm{c}}$ and Marc Vérin ${ }^{\mathrm{a}, \mathrm{b}, \mathrm{d}}$ \\ ${ }^{a}$ Behavior \& Basal Ganglia Research Unit (EA 4712), University of Rennes 1, Rennes, France \\ ${ }^{\mathrm{b}}$ Institut des Neurosciences Cliniques de Rennes (INCR), Rennes, France \\ ${ }^{\mathrm{c}}$ INSERM, INRAE, Université de Rennes 1, CHU de Rennes, Nutrition Metabolisms and Cancer, Rennes, France \\ ${ }^{\mathrm{d}}$ Movement Disorders Unit, Neurology Department, Pontchaillou University Hospital, Rennes, France
}

Accepted 22 June 2021

Pre-press 8 July 2021

\begin{abstract}
Despite clinical evidence of poor oral health and hygiene in Parkinson's disease (PD) patients, the mouth is often overlooked by both patients and the medical community, who generally focus on motor or psychiatric disorders considered more burdensome. Yet, oral health is in a two-way relationship with overall health-a weakened status triggering a decline in the quality of life. Here, we aim at giving a comprehensive overview of oral health disorders in PD, while identifying their etiologies and consequences. The physical (abnormal posture, muscle tone, tremor, and dyskinesia), behavioral (cognitive and neuropsychiatric disorders), and iatrogenic patterns associated with PD have an overall detrimental effect on patients' oral health, putting them at risk for other disorders (infections, aspiration, pain, malnutrition), reducing their quality of life and increasing their isolation (anxiety, depression, communication issues). Interdisciplinary cooperation for prevention, management and follow-up strategies need to be implemented at an early stage to maintain and improve patients' overall comfort and condition. Recommendations for practice, including (non-)pharmacological management strategies are discussed, with an emphasis on the neurologists' role. Of interest, the oral cavity may become a valuable tool for diagnosis and prognosis in the near future (biomarkers). This overlooked but critical issue requires further attention and interdisciplinary research.
\end{abstract}

Keywords: Parkinson's disease, oral health, stomatognathic diseases, dentistry, microbiota, interdisciplinary research

\section{INTRODUCTION}

"As far as the fields of dentistry and neurology are concerned, they should be especially close [...] I am convinced that every neurologist should know more dentistry, and that the average dentist would profit in many ways if he had more information about neurology."

\footnotetext{
${ }^{*}$ Correspondence to: Manon Auffret, PharmD, PhD, EA 4712 "Comportement et Noyaux Gris Centraux", Campus de Villejean - Bât. 40L27, 2 Rue Henri le Guilloux, 35033 Rennes Cedex, France. E-mail: auffret.manon@gmail.com, manon.auffret@ univ-rennes1.fr; ORCID: orcid.org/0000-0002-7003-4084.
}

Roland P. Mackay (1937) Points of contact between dentistry and neurology. The Journal of the American Dental Association and The Dental Cosmos 24(10), 1647-1654.

To this day, oral health is not prioritized in the management of neurodegenerative diseases. Patients, caregivers, and the medical community generally focus on other high-priority problems, like dementia or movement disorders [1, 2]. Parkinson's disease (PD) is no exception [3-5]. Yet, oral health is not isolated from general health: it is a critical component of overall health, well-being and quality of life [6-10]. 
PD is now recognized as a complex multisystem neurodegenerative disorder [11-13], with growing awareness and treatment of nonmotor symptoms [14, 15]. Patients' oral and dental health has, however, been under-documented, with a lack of high-quality studies ${ }^{1}$ and conflicting findings [17]. To our knowledge, no overview of the possible relationships between oral health, PD clinical picture and the ramification of their intricacy on general health has been published. Recent efforts have been undertaken to guide the management of PD patients within dental offices [18] and the inclusion of dentists into a new outpatient integrated ${ }^{2}$ PD care model [19-21]. This narrative review therefore aims at summarizing published literature regarding oral health in PD, exploring the interplay between oral and general health in PD and highlighting unmet needs in clinical care and research.

A literature search for original studies, case reports, case series and review articles published up to January 31, 2021 (language: English) was performed using the MEDLINE, PubMed, and Google Scholar databases, with the following inclusion criteria as search terms: "Parkinson disease", "Oral Health", "Stomatognathic Diseases", "Dentistry" (MeSH terms), "oral disorders", "dental", and "buccal" (non-MeSH terms). Reference lists of relevant articles were additionally screened to supplement electronic searching and subsequently reduce the risk of missing relevant information. Data were combined and analyzed through a multi-expertise approach involving a PD specialist (MV), neuroscientists (MA, MV), a pharmacist (MA), dentists (VM, EB, MBM), and microbiologists (VM, EB, MBM) to carry out a comprehensive review and draw new hypotheses.

We firstly report the complex picture of oral health in PD. Orofacial manifestations, weakened oral health, and reduced oral care in both home-based and professional settings are described and explained. Secondly, we summarize what is at stake for PD patients and how oral health disorders may have a

deleterious impact on the quality of life and PD progression. Thirdly, we highlight the central role of the neurologist and the need for early and close collaboration with the dental team. Such integrated care would be empowering and potentially be both short-

\footnotetext{
${ }^{1}$ According to the criteria of evidence-based medicine [16].

2 "Integrated care is designed according to the multidimensional needs of the population and the individual and is delivered by a coordinated multi- or interdisciplinary team of providers working across settings and levels of care." [19]
}

and long-term life-changing for patients. Finally, we address unmet needs by paving the way towards better awareness, assessment, and care of oral health in PD. We propose future research avenues to unravel the mechanisms of this two-way relationship and the potential diagnostic and predictive values of the oral ecosystem.

\section{ORAL HEALTH IN PARKINSON'S DISEASE: A COMPLEX PICTURE}

Oral health is multidimensional (physical, psychological, emotional, and social), subjective, and dynamic. It is essential for daily functions like eating, swallowing, speaking, and socializing [10, 22-24]. These functions involve the action of the teeth, lips, cheeks, tongue, and oro-facial-pharyngeal muscles. The imbalance caused by motor (voluntary and involuntary muscle control), nonmotor, and sensory deficits in PD leads to a variety of orofacial manifestations $[25,26]$. To date, there is no consensus regarding the most prevalent issues in PD patients, and results vary across studies [3, 4, 21, 27, 28]. Several factors may account for these discrepancies [1, $4,29,30$ ], as many papers failed to adjust for clinical, environmental, and pharmaceutical variables. Differences are identified within study populations: gender, age, comorbidities, and subjects randomly selected or actively seeking dental treatment. Moreover, specific differences are also found within PD groups: idiopathic PD versus parkinsonism, PD stage, subtype, severity, and duration, antiparkinsonian medications, living at home versus institutionalized. The quality, accessibility and affordability of the healthcare systems also account for discrepancies. Other contributing factors are methodological: subjective and objective assessments, questionnaires, and ambiguous definitions. However, all studies but two $[29,30]$ point out towards a weakened or disturbed oral status with objective and subjective differences between PD patients and control groups.

\section{Orofacial manifestations of PD}

PD is characterized by a wide range of motor and nonmotor symptoms, stemming from both dopaminergic and non-dopaminergic alterations [14, 31]. These symptoms include a variety of orofacial manifestations, underpinned by sensory and motor dysfunction, occurring in premotor, early, and later stages [25]. Hyposmia is a well-known prodromal sign $[31,32]$. However, other orofacial manifesta- 
tions can also precede the onset of motor symptoms and be presenting features: hyposialorrhea [33], tongue tremor [34-36], upper-body axial symptoms [37], or even dysphagia on rare occasions [38]. Speech disorders, dysphagia, and drooling are the most frequently described orofacial disorders in PD throughout the disease course [14, 25, 31, 39, 40]. At least one of these symptoms was found in more than half $(65 \%)$ of a cohort of 419 French PD patients, whilst a combination of symptoms was present in one third of them [41]. Regardless of disease duration, drooling, appetite/weight, speech, loss of smell/taste and swallowing disorders all appear in the list of the " 24 most bothersome PD-related symptoms/conditions" as evaluated by patients themselves [42]. Notably, the loss of smell/taste is one of the 5 most prevalent complains in early PD ( $<6$ years), while drooling is one of the 5 most prevalent complaints in late PD ( $\geq 6$ years) [42]. As these disorders have been extensively described and studied in the literature, this article will not focus on them (for recent reviews, please refer to the following references: dysphagia [43, 44], speech disorders [45, 46], and sialorrhea [47]). Functional changes of the anatomic system comprising teeth, jaws and associated soft tissues are reported in PD. They include masticatory and temporomandibular joint disorders (muscle rigidity and incoordination, reduced muscle tone) [5, 25, 26, 48-54], hypomimia, tremor, dyskinesia [55], dystonia [56], oral festination [57], and orofacial pain [49, 58, 59]. Dysgeusia [60-64], bruxism [54, 65, 66], and burning mouth syndrome [66-70] are also inconsistently reported.

\section{Oral health is poorer in $P D$}

Few international studies have been published on oral health in PD patients (Table 1; for detailed results, please refer to Supplementary Table 1). Differences in methodologies, populations, and countries (underpinning differences in health care accessibility and affordability) are notable, which complicates both the interpretation and comparison of results. However, while many of these studies do not represent large samples of patients (ranging from single case reports to hundreds of subjects), they highlight a concerning oral health deficit, with symptoms coexisting in different combinations. Despite being often underreported, these oral symptoms increase the overall disease burden as PD progresses [3, 5, 25, 27, 71, 72]. Compared to controls, PD patients appear to have a significantly weakened oral status $[5,27,48,68,71,72]$, with periodontal diseases ${ }^{3}$ and dental caries (tooth decay), leading to more mobile and missing teeth $[3,5,27,28,68$, 72-76]. Patients report more discomfort (pain, dry mouth, denture issues) as well as chewing difficulties (related to either teeth, denture, or masticatory function) and dysphagia. They have a worse perception of their oral health $[3,77]$, and a decreased oral health-related quality of life $[4,48,52,69,71,72,78$, 79]. Of interest, changes in the oral microbiota are also reported, though the significance and extent of such alterations, as well as their link with PD remain to be determined (causal/correlative/consecutive) [74, 80-82].

This significant oral health inequality is associated with difficulties in coping with dental treatment at the dental office and a decreased ability to maintain adequate levels of daily home oral care, arising from both motor and nonmotor disorders [5, 83].

\section{PD: An impediment to oral and dental care}

Despite being aware of the importance of good oral care and displaying normal to high toothbrushing habits and yearly dental visits $[3,29,30,69$, $72,74,75]$, PD patients do not seem to perform and receive sufficient quality of care. This could be related to the fact that PD has direct and indirect impact on oral health and hygiene. As highlighted in Fig. 1, the physical, psychological, and iatrogenic (see Table 2) patterns associated with PD are predisposing factors of diminished oral health $[5,26,69$, 72, 84-98]. PD severity and duration are both associated with an increased severity of orofacial and dental problems [5, 25, 27, 48, 72]. Motor difficulties, cognitive deficiencies and behavioral changes (food and hygiene habits) compromise daily activities, reducing the quality and quantity of daily oral care and dental care utilization [1, 69, 71, 72]. Additionally, PD patients are more prone to falls, owing to several conditions, such as gait disorders, postural instability and orthostatic hypotension $[99,100]$. Falls can in turn lead to maxillofacial trauma and traumatic dental injuries [101].

\footnotetext{
${ }^{3}$ Periodontal diseases are characterized by inflammation of tissues surrounding the teeth. They are of two types: gingivitis (non-destructive and reversible inflammation usually associated with bacteria accumulation) and periodontitis (chronic and dysregulated inflammation associated with multispecies bacterial community characterized by irreversible alveolar bone loss surrounding the teeth, leading to its mobility and loss).
} 
Table 1

Summary of the main findings found in international literature regarding oral health disorders in patients with Parkinson's disease (orofacial symptoms, oral health, oral hygiene). For detailed results, please refer to Supplementary Table 1

\begin{tabular}{|c|c|c|c|c|c|}
\hline \multirow[t]{2}{*}{ Reference/country } & \multirow{2}{*}{$\begin{array}{l}\text { Methodology: Subjects, type of } \\
\text { assessments and study design }\end{array}$} & \multirow{2}{*}{$\begin{array}{l}\text { Direct and indirect orofacial } \\
\text { consequences of PD and } \\
\text { PD medication }\end{array}$} & \multicolumn{3}{|c|}{ Main findings for patients with PD } \\
\hline & & & Oral health disorders & Oral hygiene & Conclusion \\
\hline $\begin{array}{l}\text { Anastassiadou et al., } 2002 \\
\text { [73]/Greece }\end{array}$ & $\begin{array}{l}\text { - } N=51, \text { all PD stages } \\
\text { - No control group } \\
\text { - Objective \& subjective } \\
\text { assessments } \\
\text { - Cross-sectional study }\end{array}$ & $\begin{array}{l}\text { - Hypomimia, speech } \\
\text { difficulties, facial muscles } \\
\text { rigidity, facial tremor } \\
\text { - Xerostomia, drooling, } \\
\text { chewing, dysphagia, nausea } \\
\text { - Preference for soft food }\end{array}$ & $\begin{array}{l}\text { Periodontal diseases }{ }^{\#}, \text { dental } \\
\text { caries, erosion, denture } \\
\text { problems, ulcer, } \\
\text { hyperplasia, chewing } \\
\text { (related to teeth or denture), }\end{array}$ & $\begin{array}{l}\text { - Reduced } \\
\text { - Assistance needed }\end{array}$ & $\begin{array}{l}\text { - Orofacial, oral and } \\
\text { dental disorders in PD } \\
\text { - No association with } \\
\text { PD duration }\end{array}$ \\
\hline $\begin{array}{l}\text { Bakke et al., } 2011 \\
\text { [48]/Denmark }\end{array}$ & $\begin{array}{l}-N=15, \text { mean PD duration } 6.7 \\
\quad \pm 3 \text { y, Hoehn \& Yahr stages 2-4 } \\
\text { - Matched control subjects } \\
\text { - Objective \& subjective } \\
\text { assessments } \\
\text { - Case control study }\end{array}$ & $\begin{array}{l}\text { - Impaired masticatory } \\
\text { function } \\
\text { - Drooling, reduced opening } \\
\text { capacities }\end{array}$ & NA & NA & $\begin{array}{l}\text { - Increased impairment } \\
\text { masticatory function } \\
\text { with PD severity }\end{array}$ \\
\hline $\begin{array}{l}\text { Barbe et al., } 2017 \\
\text { [3]/Germany }\end{array}$ & $\begin{array}{l}-N=100, \text { mean PD duration } \\
\quad 9.5 \pm 6 \text { y } \\
\bullet \text { No control group } \\
\text { - Subjective assessments } \\
\text { - Cross-sectional study }\end{array}$ & $\begin{array}{l}\text { - Snacking behavior } \\
\text { - Xerostomia, drooling, } \\
\text { dysphagia }\end{array}$ & NA & $\begin{array}{l}\text { - Reduced } \\
\text { - Lack of dental advise }\end{array}$ & $\begin{array}{l}\text { - Increased impairment } \\
\text { with PD duration }\end{array}$ \\
\hline $\begin{array}{l}\text { Barbe et al., } 2017 \\
\text { [77]/Germany }\end{array}$ & $\begin{array}{l}\text { - } N=26 \text {, mean PD duration } 9 \pm 4 \text { y } \\
\text { - Matched control subjects } \\
\text { - Objective \& subjective } \\
\text { assessments } \\
\text { - Case control study }\end{array}$ & $\begin{array}{l}\text { - Altered taste sensation } \\
\text { - Xerostomia }\end{array}$ & $\begin{array}{l}\text { - Periodontal diseases } \\
\text { (periodontitis), halitosis }\end{array}$ & NA & $\begin{array}{l}\text { - Impaired oral } \\
\text { health-related quality } \\
\text { of life }\end{array}$ \\
\hline Cicciù et al., 2012 [68]/Italy & $\begin{array}{l}\text { - } N=45, \text { Hoehn \& Yahr stages } \\
\text { 1-2 } \\
\text { - Matched control subjects } \\
\text { - Objective assessments \& } \\
\text { interview } \\
\text { - Case control study }\end{array}$ & $\begin{array}{l}\text { - Discomfort with } \\
\text { mouthwashes (fear of } \\
\text { choking?) }\end{array}$ & $\begin{array}{l}\text { - Periodontal diseases } \\
\text { (periodontitis), mobile and } \\
\text { missing teeth }\end{array}$ & - Reduced & $\begin{array}{l}\text { - Poorer oral health in } \\
\text { patients with PD }\end{array}$ \\
\hline $\begin{array}{l}\text { Clifford \& Finnerty, } 1995 \\
\text { [69]/United Kingdom } \\
\text { (England \& Northern } \\
\text { Ireland) }\end{array}$ & $\begin{array}{l}\text { - } N=228, \text { median age } 69.5 \mathrm{y}, \\
\text { members of a PD society } \\
\text { - No control group } \\
\text { - Subjective assessments } \\
\text { (self-reporting, postal } \\
\text { questionnaire) } \\
\text { - Cross-sectional study }\end{array}$ & $\begin{array}{l}\text { - Xerostomia, dysphagia, } \\
\text { burning mouth syndrome } \\
\text { - Difficulties with dental } \\
\text { appointment (anxiety, } \\
\text { affordability, accessibility) }\end{array}$ & $\begin{array}{l}\text { - Periodontal disease } \\
\text { (periodontitis), denture } \\
\text { problems, ulcer, mobile } \\
\text { teeth }\end{array}$ & - Reduced & $\begin{array}{l}\text { - Oral health disorders } \\
\text { - Stress with dental } \\
\text { appointment }\end{array}$ \\
\hline
\end{tabular}




\begin{tabular}{|c|c|c|}
\hline $\begin{array}{l}\text { Einarsdóttir et al., } 2009 \\
\text { [74]/Iceland }\end{array}$ & $\begin{array}{l}\text { - } N=67 \\
\text { - Control subjects (spouse or } \\
\text { family member) } \\
\text { - Objective \& subjective } \\
\text { assessments } \\
\text { - Case control study }\end{array}$ & $\begin{array}{l}\text { - Difficulties with dental } \\
\text { appointment (affordability, } \\
\text { Patients and dentist } \\
\text { reluctance?) }\end{array}$ \\
\hline Frota et al., 2016 [224]/Brazil & $\begin{array}{l}-N=35, \text { mean age } 71.3 \text { y } \\
\text { - Control groups (healthy control } \\
\text { and Alzheimer's disease) } \\
\text { - Objective assessments } \\
\text { - Case control study }\end{array}$ & - Angular cheilitis \\
\hline $\begin{array}{l}\text { Fukayo et al., } 2003 \\
\text { [29]/Japan }\end{array}$ & $\begin{array}{l}-N=31, \text { aged } \geq 60 \text { y, Hoehn } \& \\
\text { Yahr stages } \mathbf{1}-\mathbf{3} \\
\text { - Control group }(N=104, \\
\text { aged } \geq 60 \text { y) } \\
\text { - Objective \& subjective } \\
\text { assessments } \\
\text { - Case control study }\end{array}$ & - Preference for soft food \\
\hline $\begin{array}{l}\text { Hanaoka \& Kashihara, } 2009 \\
\text { [27]/Japan }\end{array}$ & $\begin{array}{l}-N=89, \text { mean PD duration } \\
5.9 \pm 5.0 \text { y } \\
\text { - Control groups age-matched } \\
\text { (mild neurological disease and } \\
\text { acute and ischemic stroke) } \\
\text { - Case control study }\end{array}$ & NA \\
\hline $\begin{array}{l}\text { Kennedy et al., } 1994 \\
\text { [80]/USA }\end{array}$ & $\begin{array}{l}-N=28 \text { non-demented PD } \\
\text { patients, mean PD duration } \\
\sim 9 \pm 5.0 \text { y, mean Hoehn } \boldsymbol{\&} \\
\text { Yahr stage } \sim \mathbf{3} \pm \mathbf{0 . 8} \text {, divided } \\
\text { into } 2 \text { groups: "crave sweets" and } \\
\text { "not crave sweets" } \\
\text { - Control group (age and sex, mean } \\
\text { age }=64.1 \pm 6.8 \text { y) } \\
\text { - Objective assessments } \\
\text { - Case control study }\end{array}$ & - Xerostomia \\
\hline
\end{tabular}

- Periodontal diseases (periodontitis), denta caries, missing teeth

- Higher counts of cariogenic bacteria (Streptococcus mutans \& lactobacilli)

- Periodontal diseases (periodontitis), dental caries, denture problems, missing teeth, bruxism NA

- Better

- Periodontal diseases (periodontitis), denta caries, missing teeth

- Mucositis

- Higher counts of cariogenic

bacteria (Streptococcus

mutans)
- Reduced

- Poorer oral health in patients with PD

No difference in oral disease between PD and $\mathrm{AD}$ group

- Better dental status*

- Higher oral health disorders even in early stage of PD

- More mucositis and higher counts in

cariogenic bacteria in patient with PD 
Table 1

(Continued)

\begin{tabular}{|c|c|c|c|c|c|}
\hline \multirow[t]{2}{*}{ Reference/country } & \multirow{2}{*}{$\begin{array}{l}\text { Methodology: Subjects, type of } \\
\text { assessments and study design }\end{array}$} & \multirow{2}{*}{$\begin{array}{l}\text { Direct and indirect orofacial } \\
\text { consequences of PD and } \\
\text { PD medication }\end{array}$} & \multicolumn{3}{|c|}{ Main findings for patients with PD } \\
\hline & & & Oral health disorders & Oral hygiene & Conclusion \\
\hline Lyra et al., 2020 [75]/Portugal & $\begin{array}{l}-N=28, \text { mean age } 72.3 \pm 8.1 \mathrm{y} \text {, } \\
\text { idiopathic PD }(82.1 \%) \text { or other } \\
\text { parkinsonisms, mild to severe } \\
\text { motor impairment } \\
\text { - No control group } \\
\text { - Objective \& subjective } \\
\text { assessments } \\
\text { - Cross-sectional study }\end{array}$ & - Xerostomia & $\begin{array}{l}\text { - Periodontal diseases } \\
\text { (periodontitis), mobile and } \\
\text { missing teeth }\end{array}$ & - Reduced & $\begin{array}{l}\text { - Association between } \\
\text { PD progression } \\
\text { (upper extremity } \\
\text { rigidity, hand posture } \\
\text { and tremor) and } \\
\text { impaired oral hygiene } \\
\text { habits and severity of } \\
\text { periodontitis }\end{array}$ \\
\hline $\begin{array}{l}\text { Müller et al., } 2011 \\
\text { [28]/Germany }\end{array}$ & $\begin{array}{l}\text { - } N=101, \text { mean age } 66.2 \pm 10.5 \text { y; } \\
\text { Hoehn \& Yahr stages 1-4 } \\
\text { - Unmatched control subjects } \\
\text { - Objective \& subjective } \\
\text { assessments, including a blind } \\
\text { assessment (clinical status/dental } \\
\text { hygienist) } \\
\text { - Case control study }\end{array}$ & - Reduced salivary flow & $\begin{array}{l}\text { - Periodontal diseases } \\
\text { (periodontitis), dental } \\
\text { caries, mobile teeth. }\end{array}$ & - Reduced & $\begin{array}{l}\text { - Poorer oral health in } \\
\text { patients with PD }\end{array}$ \\
\hline $\begin{array}{l}\text { Nakayama et al., } 2004 \\
{[71] / J a p a n}\end{array}$ & $\begin{array}{l}-N=104, \text { aged }>60 \text { y, Hoehn } \& \\
\text { Yahr stages 3-5 } \\
\text { - Control group }(N=191, \\
\text { age } \geq 60 \mathrm{y}) \\
\text { - Objective \& subjective } \\
\text { assessments } \\
\text { - Case control study }\end{array}$ & $\begin{array}{l}\text { - Dysphagia } \\
\text { - Difficulties with dental } \\
\text { appointment (accessibility) }\end{array}$ & $\begin{array}{l}\text { Periodontal diseases } \\
\text { (gingivitis), missing teeth, } \\
\text { denture problem, chewing } \\
\text { difficulties (related to teeth } \\
\text { or denture) }\end{array}$ & $\begin{array}{l}\text { - Reduced } \\
\text { - Assistance needed } \\
\text { - Lack of dental advise }\end{array}$ & $\begin{array}{l}\text { - Complain about oral } \\
\text { health } \\
\text { - Difficulties with } \\
\text { denture (in/out) } \\
\text { - Expect home visiting } \\
\text { dental service }\end{array}$ \\
\hline $\begin{array}{l}\text { Persson et al., } 1992 \\
\text { [30]/Sweden }\end{array}$ & $\begin{array}{l}-N=30, \text { mean age } 73 \pm 7.3 \mathrm{y}, \\
\text { mean PD duration } 11 \pm 5.4 \mathrm{y} \\
- \text { Control group }(N=585 \text {, geriatric } \\
\text { population age } \geq 70 \mathrm{y}) \\
\text { - Objective \& subjective } \\
\text { assessments } \\
\text { - Case control study }\end{array}$ & $\begin{array}{l}\text { - Dysphagia } \\
\text { - Motor symptoms } \\
\text { (impairment of motor skills) }\end{array}$ & NA & - Reduced & $\begin{array}{l}\text { - Good oral health** } \\
\text { - Difficulties in } \\
\text { performing oral } \\
\text { hygiene correlated to } \\
\text { the severity of } \\
\text { hypokinesia }\end{array}$ \\
\hline
\end{tabular}


Pradeep et al., 2015 [72]/India
- $N=45$, mean age $64.5 \pm 9.1 \mathrm{y}$, divided into 5 groups according

to Hoehn \& Yahr stages

- Control group (age-matche

familly member)

- Objective (blinded) \& subjective

assessments

- Case control study

Ribeiro et al., 2016 [4]/Brazil $\bullet N=17$ removable prosthesis

wearers PD patients, mean age $69.6 \pm 5.1 \mathrm{y}$, mean PD duration $6.8 \pm 3.8 \mathrm{y}$

- Control group $(N=20$ removable prosthesis control, mean age $72.0 \pm 5.7$ y)

- Objective \& subjective

assessments

- Case control study

- $N=70$, mean age 64.5 y

- Control subjects, age-matched

- Objective assessment

- Case control study

- $\mathrm{N}=74$, mean age $70.2 \pm 8.8 \mathrm{y}$,

mean PD duration $9.1 \pm 6.4 \mathrm{y}$

Hoehn \& Yahr stages 1-5

- Matched group control

- Objective \& subjective

assessments

- Case control study
- Periodontal diseases (periodontitis)

- Motor symptoms
- Reduced (deteriorating with - Deteriorating oral PD severity) health in PD patients even at early stage (Hoehn and Yahr stage 1)

Negative perception of oral health but no objective difference (PD severity not recorded)

$\begin{array}{ll}\begin{array}{l}\text { - Motor symptoms } \\ \text { (impairment of motor skills) }\end{array} & \begin{array}{l}\text { Periodontal diseases } \\ \text { (periodontitis) }\end{array} \\ & \\ \text { - Altered taste sensation } & \begin{array}{l}\text { Periodontal diseases } \\ \text { (periodontitis), dental } \\ \text { - Xerostomia } \\ \end{array} \\ & \begin{array}{l}\text { caries, mobile teeth, } \\ \text { chewing difficulties (related } \\ \text { to teeth or denture) }\end{array}\end{array}$

- Reduced

- Periodontal diseases increased in patient with PD

- Reduced (deteriorating with

PD severity)

- Weakened oral health status

- Disease severity and duration were associated with more oral health and hygiene care problems

LEDD, levodopa equivalent daily dose; PD, Parkinson's disease; NA, not assessed. *Since the present study only deals with patients with mild symptoms, it should be noted that the results shown here may not be applicable to advanced PD patients. ** Authors' hypotheses: "general conscientiousness in patients and relatives". "Periodontal disease account for gingivitis, periodontitis. 


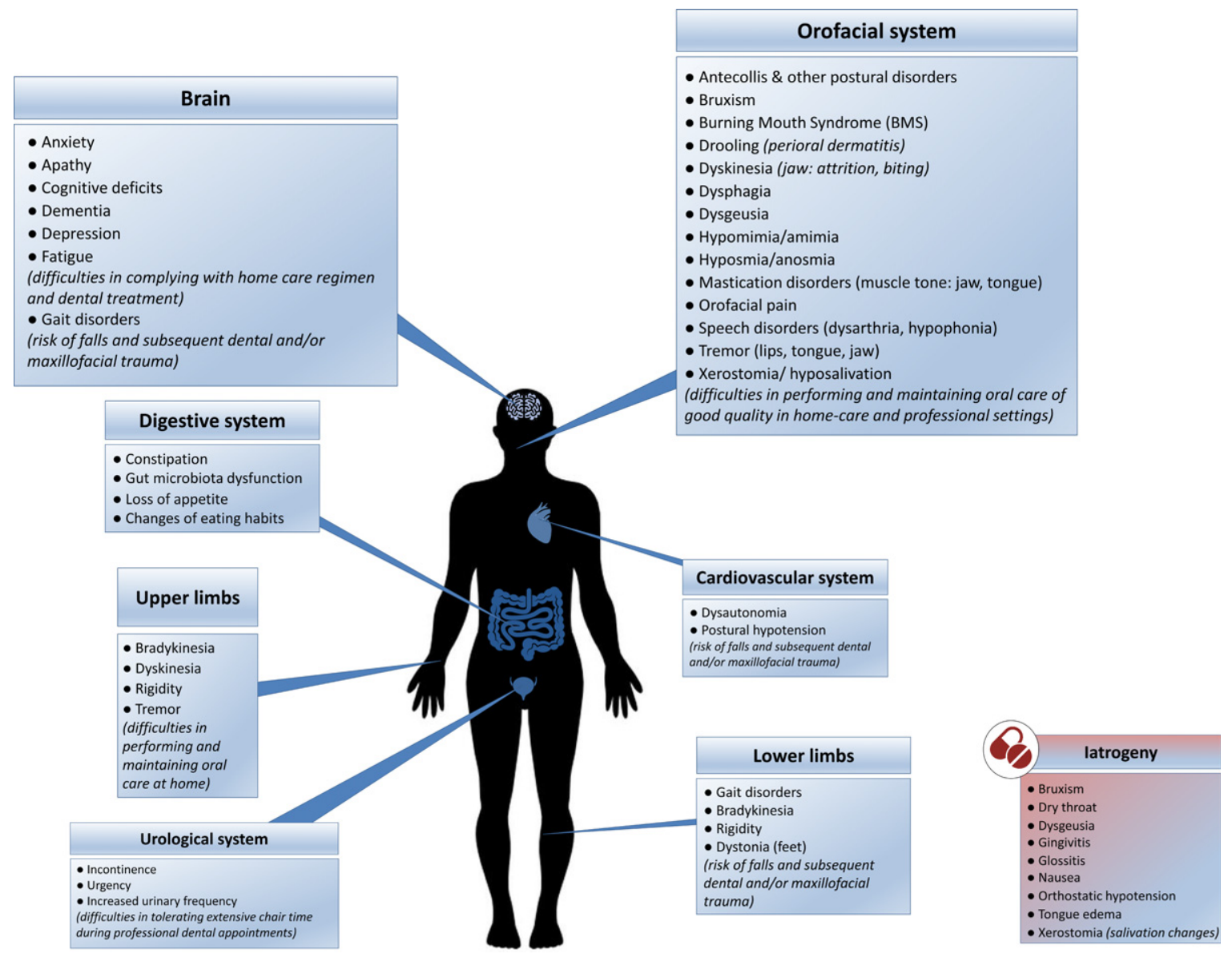

Fig. 1. The direct and indirect impact of Parkinson's disease on oral health and hygiene: contributing physical, psychological (blue boxes) and iatrogenic (red box) factors. (See online version for colour figure.)

Considering the fact that orofacial symptoms and a weakened oral health status are present even at early stages, additional factors, different from motor and cognitive impairments, may also be involved [25, 27, $28,72,81]$. (Non)dopaminergic imbalance and autonomic dysfunction likely play a role in the emergence and aggravation of these orofacial and oral health disorders [41].

\section{Problems faced in maintaining good oral care at home}

Brushing, flossing, and interproximal brushing are critical components of oral self-care [3, 41,79]. These hygiene maneuvers require muscle-eye coordination, digital dexterity, and tongue-cheek-lip control. Such actions become more difficult to achieve as PD progresses, due to tremor of hands, lips and tongue, bradykinesia, dyskinesia of the hands and jaws, fluctuations, muscle stiffness, and postural deformities $[3,4,18,28,30,48,52,76,102,103]$. Decline in the quality of the toothbrushing (not necessarily in the frequency [74]) and lack of interdental cleaning reduce the efficacy of plaque control, promoting gingivitis, and initiating or aggravating periodontitis and dental caries. Moreover, such fine movement impairments induce more difficulties in the frequency and quality of prosthesis hygiene, leading to biofilm accumulation [78]. Discomfort with mouthwashes, possibly due to dysphagia and fear of choking, has also been reported [68]. These ineffective oral hygiene measures add to the pre-existing disturbed self-cleaning mechanisms of the mouth (dysphagia, chewing disorders, oral dyskinesia and saliva changes) $[4,5,30,68,72,74,75,80]$.

Finally, when present, neuropsychiatric disorders also contribute to patients' difficulties: apathy, depression, fatigue, anosognosia, cognitive decline and dementia may all lead to negligence in daily care, making compliance with a home care regimen difficult $[1,3,28,68]$. 
Table 2

Antiparkinsonian treatments and dentistry: potential local and general side effects and drug interactions [26, 69, 84-98, 225]

\begin{tabular}{|c|c|c|}
\hline $\begin{array}{l}\text { Classification - Generic } \\
\text { names }\end{array}$ & Relevant local (orofacial) and general side effects & Interactions with drugs used in dentistry \\
\hline $\begin{array}{l}\text { Anticholinergics } \\
\text { Benztropine } \\
\text { Biperiden } \\
\text { Trihexyphenydil }\end{array}$ & $\begin{array}{l}\text { - Local: xerostomia, dry throat } \\
\text { - General: nausea/vomiting, loss of appetite, mental } \\
\text { confusion, dizziness, depression }\end{array}$ & Sedatives (e.g.: narcotic analgesics, antihistamines) \\
\hline $\begin{array}{l}\text { Botulinum toxin } \\
\text { Botulinum neurotoxin A } \\
\text { Botulinum toxin B }\end{array}$ & $\begin{array}{l}\text { - Local: dry mouth, subjective saliva thickening, oral } \\
\text { microbiota changes neck pain } \\
\text { - General: swelling, pain, nausea, drowsiness, anxiety, } \\
\text { difficulty falling asleep or staying asleep }\end{array}$ & None reported at the time of our writing \\
\hline
\end{tabular}

Dopamine receptor agonists

Apomorphine

Bromocriptine

Cabergoline

Pergolide

Pramipexole

Ropinirole

Levodopa

Levodopa-carbidopa

Levodopa-carbidopaentacapone

Enzyme inhibitors Entacapone

Rasagiline

Selegiline
- Local: none reported at the time of our writing

- General: orthostatic hypotension, nausea/vomiting, confusion

- Local: none reported at the time of our writing

- General: nausea/vomiting, heartburn, stomach cramps, loss of appetite, orthostatic hypotension

- Local: xerostomia, toothache, throat irritation

- General: nausea/vomiting, heartburn, orthostatic hypotension, fatigue

- Local: xerostomia

- General: orthostatic hypotension

- Local: dry mouth

- General: nausea, heartburn, orthostatic hypotension

- Local: xerostomia, gingivitis, glossitis, tongue edema, toothache, pharyngitis

- General: nausea/vomiting, heartburn, stomach pain, orthostatic hypotension, sedation, loss of appetite/weight loss, anxiety

- Local: xerostomia, dysgeusia, glossitis, parafunction ((awake) bruxism, clenching), glossodynia, "dark" saliva/teeth pigmentation, dysphagia, Burning mouth syndrome, mouth and throat pain, serpentine tongue, lingual protrusion dystonia, Meige's syndrome

- General: orthostatic hypotension, nausea/vomiting, dyskinesia, loss of appetite/anorexia, forgetfulness or confusion

- Local: xerostomia, dysgeusia, glossitis, parafunction ((awake) bruxism, clenching), glossodynia, "dark" saliva, teeth pigmentation, dysphagia, mouth and throat pain, dyskinesia

- General: orthostatic hypotension, nausea/vomiting, dyskinesia, loss of appetite/anorexia, forgetfulness or confusion

- Local: none reported at the time of our writing

- General: stomach pain, nausea/vomiting, drowsiness/dizziness

- Local: xerostomia, swollen gums

- General: vertigo/dizziness, nausea/vomiting, stomach pain, orthostatic hypotension, somnolence, neck pain, loss of appetite/weight loss, depression

- Local: dysgueusia, bruxism, sublingual oral ulcerations, burning lips/mouth, facial grimacing, dry mouth, difficulty swallowing

- General: nausea/vomiting, heartburn, stomach pain, orthostatic hypotension, somnolence, depression
Sedatives (e.g.: narcotic analgesics, antihistamines)

Sedatives (e.g.: narcotic analgesics, antihistamines)

Sedatives (e.g.: narcotic analgesics, antihistamines)

Sedatives (e.g.: narcotic analgesics, antihistamines)

Sedatives (e.g.: narcotic analgesics, antihistamines)

- Fluoroquinolones (CYP1A2 inhibitor $\rightarrow$ influence the elimination of ropinirole)

- Sedatives (e.g.: narcotic analgesics, antihistamines)

- Anesthetic agents containing epinephrine (blood pressure \& heart rate)

- Benzodiazepines (sedation, hypotension)

- Promethazine, prochlorperazine \& droperidol (block dopaminergic receptors within the central nervous system)

- Anesthetic agents containing epinephrine (blood pressure \& heart rate)

- Erythomycin \& ampicillin (interfere with biliary excretion of entacapone)

- Benzodiazepines (sedation, hypotension)

- Promethazine, prochlorperazine \& droperidol (block dopaminergic receptors within the central nervous system)

- May potentiate the chronotropic and arrhythmogenic effects of isoproterenol and epinephrine

- Erythomycin \& ampicillin (interfere with biliary excretion of entacapone)

- Meperidine hydrochloride (hyperthermia, hypertension, tachycardia)

- Fluoroquinolones (CYP1A2 inhibitor $\rightarrow$ influence the elimination of rasagiline)

- Pethidine (hyperthermia, delirium, muscle rigidity)

- Levonordefrin (severe hypertension)

- Epinephrin (severe hypertension)

- Meperidine, propoxyphene (acute serotonin

syndrome/ hypertensive crisis, seizures, and coma)

- Pethidine (hyperthermia, delirium, muscle rigidity) 
Table 2

(Continued)

\begin{tabular}{lll}
\hline $\begin{array}{l}\text { Classification - Generic } \\
\text { names }\end{array}$ & Relevant local (orofacial) and general side effects & Interactions with drugs used in dentistry \\
\hline $\begin{array}{l}\text { N-methyl-d-aspartate } \\
\begin{array}{l}\text { (NMDA) receptor } \\
\text { antagonists }\end{array}\end{array}$ & & \\
Amantadine & $\begin{array}{l}\text { L Local: xerostomia } \\
\text { - General: nausea/vomiting, decreased appetite, } \\
\text { orthostatic hypotension, mental confusion }\end{array}$ & Sedatives (e.g.: narcotic analgesics, antihistamines) \\
$\begin{array}{l}\text { Surgical treatment } \\
\text { Deep Brain Stimulation }\end{array}$ & $\begin{array}{l}\text { Surgical and device related: infections, mental status } \\
\text { change }\end{array}$ & Diathermy, electrocautery (thermic neural lesion) \\
& $\begin{array}{l}\text { Stimulation-induced: neuropsychiatric disorders } \\
\text { (depression), dysarthria (loss of verbal fluency), }\end{array}$ & \\
& postural instability/gait disturbances & \\
\hline
\end{tabular}

\section{Dental appointments: a challenge to both patients and dentists}

The use of dental care services mainly depends on their accessibility (distance, transportation, reduced mobility access) and affordability (healthcare system, dental insurance, socioeconomic status) [10, 104, 105]. While several barriers have been identified at the individual, organizational and policy levels [104] for elders and vulnerable people, PD patients have to face even more challenges in accessing and undergoing dental treatment.

Cognitive decline and dementia may prevent patients from reporting oral and dental symptomatology and complying with dental treatment $[1,106]$. In addition, cognitive disorders make them more likely to miss dental appointments or react with careresistant behavior [107] when receiving assistance $[1,106]$.

For dental clinicians, PD patients are a challenge, as PD symptoms complicate treatment plans, execution, and outcome [1, 18, 86, 108, 109]. Akinesia, hypokinesia, bradykinesia, gait disorders, orthostatic hypotension, postural deformities [103, 110], and muscle related problems (spasms, rigidity, tremors, and dyskinesia) cause difficulties in getting in and out of the dental chair and staying still during dental treatment $[18,86]$. Because of motor and nonmotor fluctuations, patients' behavior can change from minute to minute and may require stopping dental procedures [18, 83], while anxiety and stress worsen motor symptoms [111]. Muscle rigidity, poor muscle control (lips, jaw, tongue), oral festination [57], facial dystonia [56], orolingual tremor [34, 35, 112-114], dyskinesia (flycatcher tongue), impaired neck and head posture, or dysphagia (saliva accumulation) lead to difficulties in dental examination and oral rehabilitation [30, 48, 83, 102, 108, 109], and can even compel the use of general anesthesia [102].
The supine position during dental procedures may increase the risk of aspiration and ingestion of dental instruments, adding to the already existing risk factors related to PD [26, 115]. Fatigue, urinary [116] and bowel issues may require treatment cessation, preventing extensive treatment plans which require extended chair time $[18,83,86,106,108]$.

Finally, dentists may have limited knowledge and experience regarding the specific needs and management of PD patients [17, 74, 86, 102]. The patient-dentist relationship is hampered by several PD-related verbal and non-verbal communication impairments. Hypomimia and amimia [117] are linked with reduced facial expressiveness, fixed gaze, disruption of facial emotion recognition [118], and alterations in the facial expression of pain [119]. Speech and language disorders [45, 46, 120] (dysarthria, hypophonia) directly impair verbal communication, while cognitive impairment as well as micrography and other handwriting abnormalities [121] complicate the picture.

Although not surprising to the neurologist, these issues can become very difficult to overcome and lead to frustrating situations for both patient and dental practitioner if the professional is not aware of them and is therefore unable to adjust. Such challenges make patients and dental team reluctant to embark on complex dental procedures $[17,74,86]$. As a result, orofacial symptoms in PD are rarely assessed and detected, making them unaddressed for too long [106].

\section{ORAL HEALTH DISORDERS: WHAT IS AT STAKE FOR PD PATIENTS? A REVIEW AND NEW HYPOTHESES}

Oral diseases are associated with a variety of local and general disorders [6, 10, 24, 122-126] 
and can severely impair quality of life [7, 22]. Being chronic and progressive, they are major functional, psychosocial and economic burdens [10], like PD. Epidemiological data, and studies on microbiological and inflammatory processes have highlighted a link between dysregulated immune and inflammatory response in periodontitis and the initiation and progression of systemic diseases, such as diabetes, cardiovascular disease (atherosclerosis, stroke), cancer, Alzheimer's disease, or respiratory tract infections $[6,9,123,127-130]$. The inattention to oral health is therefore concerning in PD patients, considering its direct (pain, orofunctional problems, psychosocial wellbeing) and indirect (increased risk of infections, inflammation and systemic diseases) impacts (Figs. 2 and 3). Table 3 summarizes the possible etiologies and contributing factors to oral health disorders in PD patients, their consequences on general health and available prevention/management strategies.

Polypharmacy, motor disorders, cognitive impairment, and the subsequent decline in dental care utilization put patients at risk for dental caries and periodontal diseases (Table 1), paving the way to tooth mobility and, finally, tooth loss [131]. Speech disorders, drooling, halitosis and tooth loss impair appearance and phonetics, reducing social life and increasing isolation, thereby triggering a decline in quality of life [4, 79, 132-134].

A compromised oral health and impaired orofacial function can alter basic function like eating [132, 135], negatively impacting food intake [136, 137]. In PD, taste disturbances, hyposmia/anosmia [64, 138], orofacial pain, masticatory disorders and dysphagia [52, 136, 139] induce prolonged mealtimes and ingestion of insufficiently masticated food, putting the patient at risk of a decline in the quality and quantity of food intake, up to malnutrition. Gastrointestinal disorders may also arise and hamper drug absorption [140, 141]. Conversely, changes in eating habits [142] may favor cariogenic environments, inducing oral diseases [74, 80, 143]. Such modifications include taste preferences [61, 64, 144] and craving for sweets [80], need for softer food [73] or high-energy food supplements, and use of syrupbased medications [145].

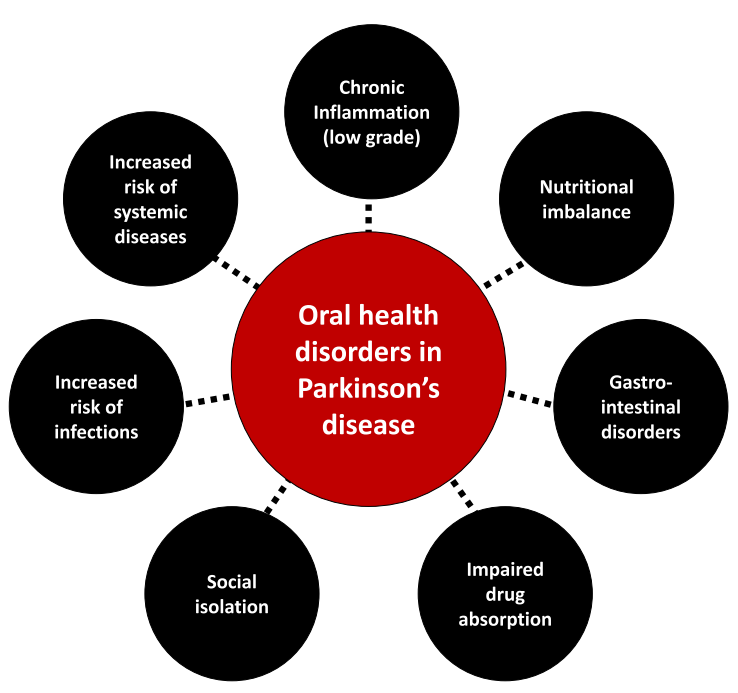

Fig. 2. More than meets the eye: Consequences of oral health disorders in Parkinson's disease.

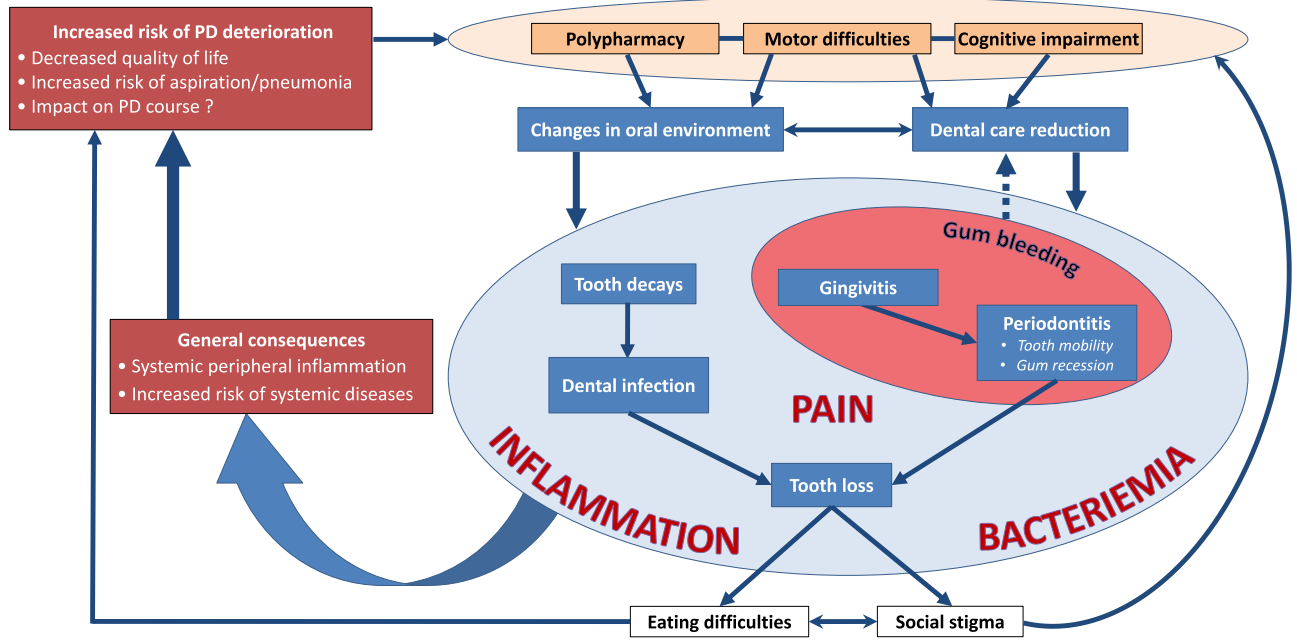

Fig. 3. The interplay between oral health disorders and Parkinson's disease. 
Table 3

Oral health disorders in parkinsonian patients: symptoms, etiologies, consequences (on local \& general health) and available prevention and management strategies

\begin{tabular}{|c|c|c|c|}
\hline Symptom & Etiologies - Contributing factors & Consequences & Prevention and management strategies \\
\hline $\begin{array}{l}\text { Dysphagia } \\
{[3,23,27,39,42-45,141,147,148,} \\
151,190,218,231-234] \\
{[3,21,38,39,41,43,44,47,139,142,} \\
145,148,153,173,174,226-230]\end{array}$ & $\begin{array}{l}\text { Prevalence: } 35 \% \text { subjective vs } 82 \% \text { objective } \\
\text { - DA (supramedullary swallowing system) \& } \\
\text { non DA mechanisms (Lewy body pathology, } \\
\text { substance P) } \\
\text { - Poor lip seal \& saliva accumulation } \\
\text { - Tongue rigidity and repetitive pumping action } \\
\text { - Delayed swallowing } \\
\text { - Irregular movements of the epiglottis } \\
\text { - Impaired esophagus peristalsis } \\
\text { - Low body weight } \\
\text { - Female gender } \\
\text { - Drug-induced: botulinum toxins (rare) }\end{array}$ & $\begin{array}{l}\text { - Increased risk of choking, aspiration and } \\
\text { pneumonia } \\
\text { - Gastro-esophageal reflux } \\
\text { - Eating difficulties, modification of food } \\
\text { choices and intake limitations ( } \rightarrow \\
\text { malnutrition, dehydration, weight loss) } \\
\text { - Isolation, reduced social contact } \\
\text { ( } \rightarrow \text { depression) } \\
\text { - Fear \& anxiety } \\
\text { - Impaired pill swallowing and possible reduced } \\
\text { efficacy of oral medications } \\
\text { - Reduced quality of life } \\
\text { - Colonization of the oropharynx with } \\
\text { Gram-negative bacilli }\end{array}$ & $\begin{array}{l}\text { - Eating habits: cut food into smaller pieces, } \\
\text { alter texture and consistency to facilitate } \\
\text { swallowing } \\
\text { - Oral hygiene: avoid mouthwashes (or prefer } \\
\text { non-alcoholic, fluoridated mouthwashes) } \\
\text { - Speech \& language therapy - Biofeedback } \\
\text { - Pharmacological interventions, including } \\
\text { dopaminergic medication optimization } \\
\text { - Sugar-free gums }\end{array}$ \\
\hline $\begin{array}{l}\text { Hypomimia } \\
{[25,26,31,42,118]}\end{array}$ & $\begin{array}{l}\text { - DA deficiency } \\
\text { - Reduced muscle tone, reduced blinking rate } \\
\text { - Male gender }\end{array}$ & $\begin{array}{l}\text { - Impaired verbal \& non-verbal communication } \\
\text { - Impaired emotion recognition (social skill) } \\
\text { - Drooling } \\
\text { - Social stigma }\end{array}$ & $\begin{array}{l}\text { - Speech therapy to enhance verbal } \\
\text { communication (facial mobility) }\end{array}$ \\
\hline $\begin{array}{l}\text { Speech disorders } \\
{[25,41,45,46,231,232]} \\
\text { e.g.: dysarthria, hypophonia, } \\
\text { slurred words, fast speech, or } \\
\text { hesitation before speaking }\end{array}$ & $\begin{array}{l}\text { Up to } 89 \% \text { of patients } \\
\text { - Oropharyngeal bradykinesia } \\
\text { - Xerostomia \& oral irritation } \\
\text { - Motor \& nonmotor deficits (PD) } \\
\text { - Male gender }\end{array}$ & $\begin{array}{l}\text { - Difficulties in communication } \\
\text { - Isolation, reduced social contact } \\
\text { - Marginalization from discussions about } \\
\text { clinical care }\end{array}$ & $\begin{array}{l}\text { - Speech therapy (voice modulation, volume, } \\
\text { intonation, articulation) } \\
\text { - Prosthetic rehabilitation and follow-up }\end{array}$ \\
\hline $\begin{array}{l}\text { Altered taste sensation } \\
{[5,61,64,138,144,233]} \\
\text { (e.g., reduced food flavor, bad } \\
\text { taste in the mouth) }\end{array}$ & $\begin{array}{l}\text { Up to } 27 \% \\
\text { - Drug-induced dysgeusia (levodopa, pergolide) } \\
\text { - Olfactory dysfunction (hyposmia, anosmia) } \\
\text { - Reduced saliva secretion } \\
\text { - Acid reflux, heartburn } \\
\text { - PD-associated (CNS degeneration) } \\
\text { - Nausea (levodopa and dopaminergic agonists) }\end{array}$ & $\begin{array}{l}\text { - Decreased appetite, loss of interest in ingesting } \\
\text { food, modification of food choices } \\
\text { - Discomfort } \\
\text { - Decrease in oral hygiene }\end{array}$ & $\begin{array}{l}\text { - Food changes (nausea) } \\
\text { - Domperidone (nausea) } \\
\text { - Drug adjustments (drug-induced side effect) }\end{array}$ \\
\hline $\begin{array}{l}\text { Xerostomia (subjective) } \\
\text { Hyposalivation (objective) } \\
{[5,18,26,69,80,81,86,115,233,234]}\end{array}$ & $\begin{array}{l}\text { Up to } 87 \% \\
\text { - Autonomic disorders } \\
\text { - Drug-induced: } \\
\text { - anticholinergic drugs, } \\
\text { - Levodopa (may reduce salivary secretion) } \\
\text { - dopaminergic drugs, } \\
\text { - botulinum toxins } \\
\text { - Reduced saliva rate flow }\end{array}$ & $\begin{array}{l}\text { - Reduces antibacterial and cleansing action of } \\
\text { saliva and tongue } \rightarrow \text { risk factor for oral } \\
\text { diseases and lesions } \\
\text { - Changes of the microbiota } \\
\text { - Discomfort and increased risk of painful oral } \\
\text { soft tissue lesions leading to denture issues } \\
\text { - Eating difficulties: dysgueusia, chewing } \\
\text { difficulties } \rightarrow \text { reduced nutritional status } \\
\text { - Speech problems }\end{array}$ & $\begin{array}{l}\text { - Lubricating sprays (malic acid), } \\
\text { physostigmine gels, saliva substitutes } \\
\text { (particularly at meal times) \& artificial salivary } \\
\text { products (evidence grade B/moderate) } \\
\text { - Sipping water frequently } \\
\text { - Sugar-free hard candies or gums } \\
\text { (xylitol-containing) } \\
\text { - Cholinergic agonists } \\
\text { - Avoid acidic or fizzy drinks } \\
\text { - Review of current medication }\end{array}$ \\
\hline
\end{tabular}

saliva and tongue $\rightarrow$ risk factor for oral

diseases and lesions

Changes of the microbiot

Speech problem
- physostigmine gels, saliva substitues (particularly at meal times) \& artificial salivary products (evidence grade $\mathrm{B} /$ moderate)

(xylitol-containing)

Avoid acidic or fizzy drinks

Review of current medication 
Drooling

$[3,15,18,25,26,41,88,94,229,230$, 235-239]
Various prevalence depending on disease stage (10-84\%), with diurnal (23-28\%) \& nocturnal (up to $58 \%$ ) drooling

- Autonomic disorders

- Dysphagia, oropharyngeal bradykinesia, hypomimia (poor lip closure, involuntary mouth opening \& loss of facial muscle tone) $\rightarrow$ excess pooling of saliva in the mouth

- Antecollis (flexed head posture)

- Exacerbation with acute dental issues

- PD severity

- Non-dopaminergic mechanisms

- Dyskinesia

- Drug-induced (e.g. long-term use of L-dopa)

- Stress, anxiety, depression (AB)

- Reduced muscle tone (jaw, tongue, lips, oropharynx)

- Dyskinesia \& tremor (face, jaw)

- Drug-induced dyskinesia

- Teeth loss, edentulous mouth (chewing issues + impairs feedback from the periodontal ligament, temporomandibular joint, and musculature receptors)

- Xerostomia \& oral irritation

- Postural alterations

- Parafunctional habits (e.g., bruxism, lip biting), stress, anxiety
- Dermatitis, angular cheilosis, skin irritation

- Saliva $\mathrm{pH}$ changes, microbiota changes,

halitosis

- Disabling social impact (++ diurnal): embarrassment, low self-esteem, social

unacceptability and stigma

- Increased risk of silent aspiration, choking and aspiration pneumonia

- Compromised denture retention
- Attrition $\rightarrow$ teeth, implant and crowns breakage

- Trauma to the tongue

- Compromised denture retention

- Orofacial pain (temporomandibular disorders) $\&$ headaches

- Swallowing \& speech disorders

- Depression

- Chewing disorders, impaired food intake, preference for softer food $(\rightarrow$ malnutrition, weight loss)

- Discomfort, pain (orofacial pain, toothaches)

- Biting of tongue, lips \& cheeks

- Cracked teeth

- Displaced restoration, compromised denture retention $\rightarrow$ ill-fitting dentures leading to mucosal lesions

- Limited mouth opening, jaw locking (issues with difficult dental assessment \& treatment) - Sleep disturbances, fatigue, depression
- Intrasalivary gland injection of botulinum toxin (BTX-A/B), every 3 months (evidence grade $\mathrm{A}$, high)

- Glycopyrrolate

- $1 \%$ atropine solution sublingually twice a day

- Behavioral management techniques, swallow periodically to avoid saliva build-up (conscious effort)

- MAO-B inhibitor?

- Greater sialorrhea reduction in patients with imipraminics? [10]

- During dental procedures: four-handed dentistry (assistant to suction the build-up of saliva \& avoid aspiration), patient positioned in a semi reclining $45^{\circ}$ angle

- Custom-made thermoplastic bruxism splint

Botulinum toxin injections

Benzodiazepines, antidepressants

- Dopaminergic drugs (++ SB)

- Mouthguard

- Maintenance of natural teeth trough avoidance of dental disease \& dental caries

- Cut food into smaller pieces, alter texture and consistency to facilitate swallowing

- Prosthetic rehabilitation and follow-up: intraoral occlusal appliance, implants

- Mandibular rehabilitation

- Denture hygiene

- Physical therapy 
Table 3

(Continued)

\begin{tabular}{ll}
\hline Symptom & Etiologies - Contributing factors \\
\hline $\begin{array}{l}\text { Reduced ability to perform oral } \\
\text { hygiene }\end{array}$ & $\bullet$ DA \& non DA mechanisms \\
{$[18,28,78,102,136]$} & $\bullet$ Muscle incoordination, motor impairment \\
& (tremor, reduced fine motor skills) \\
& $\bullet$ Motor fluctuations \\
& $\bullet$ Cognitive disturbances (apathy, depression, \\
& anosognosia, dementia)
\end{tabular}

Denture problems, poor denture retention

$[68,71,79,83,88,102,108,115$ $234,241]$

Increased number of caries $[18,27,28,68,74,136,149,242]$

anosognosia, dementia)

- Muscle incoordination (tongue, lips, jaw) \& inadequate amount of saliva $(\rightarrow$ lack of denture control)

- Rigid facial muscles

- Xerostomia

- Weight loss

- Oral dyskinesia

- Drug-induced oral dyskinesia

- Cariogenic environment: changes in eating habits: craving for sweets, altered taste

Consequences
sensation \& use of high-calorie dietary supplements

- Changes in salivary pH \& composition

- Xerostomia

- Reduced oral hygiene (plaque formation)

- Changes in microbiota (Streptococcus mutans. Lactobacilli)
- Increased risk of caries and periodontal diseases

- Biofilm presence on prosthesis

$\rightarrow$ risk of infections (local and general)

Prevention and management strategies

- Repeated instructions on proper brushing \&

flossing techniques

- Electronic/power toothbrushes, wider

grip/thicker handle for toothbrush

- Toothbrushes with soft bristles and small

heads (change every 3 months)

- Toothpaste pumps (squeezing difficulty with tube)

- Fluorination: professional and toothpaste

- Dental floss with floss holders \& interproximal brushes

- Denture/prosthesis hygiene (combination of mechanical and chemical methods)

- Recall dental appointments at short intervals and periodic instruction in oral health and prosthesis cleaning

- Dietary advice (to limit the induction of

cariogenic environment)

- Oral health education and home visiting dental services

- Discomfort, denture-related oral mucosal lesions: local/diffuse inflammation,

hyperplasia, ulcers

- Eating \& drinking difficulties $\rightarrow$ compound to

existing eating and swallowing issues

- Social stigma, decreased self-esteem and

social acceptability

- Biofilm accumulation (pathogens reservoir)

- Risk of aspiration

- Discomfort (pain, sensitivity)

- Local infection (inflammation, abscess)

- Dissemination of the infection

- Eventually, loss of teeth

- Risk factor for pneumonia

- Prosthetic rehabilitation and follow-up
- Water based denture adhesive

- Denture hygiene (brushing, sodium hypochlorite soaking) \& regular checkups

- Nutritional drinks (weight stabilization)

- Recall dental appointments at short intervals and periodic instruction in oral health and prosthesis cleaning

- Review of current medication (drug-induced side effect)

- Fluoridated toothpaste 2500-5000 ppm \& gels (evidence grade A, high)

- Dietary changes (avoid sweet and sticky food)

- Preventive dentistry with dentist visits every 4 months

- Electronic toothbrushes

- Alleviate xerostomi

- Removable prosthesis hygiene

- Recall dental appointments at short intervals and periodic instruction in oral health and prosthesis cleaning

- Dental flossing 
Increased prevalence and severity of periodontal diseases

(gingivitis and periodontitis)

$[5,27,28,68,72-77,224]$

- Reduced oral hygiene (plaque formation)

- Changes in salivary pH \& composition

- Xerostomia

- Microbiota dysbiosis

\section{Erosion, attrition \& teeth \\ breakage}

$[27,28,74,78,108$

Tooth loss

$[27,79,108]$

Burning mouth syndrome (BMS)

$[26,66,67,70,86,108,243,244]$
- Falls (postural hypotension, gait disorders)

- Rigor \& tremor

- Dyskinesia

- Bruxism

- Acid reflux due to dysphagia

- Changes in salivary $\mathrm{pH}$

- Caries \& periodontal disease

- Attrition \& teeth breakage (falls \& jaw

disorders)

- Removal to avoid complex dental procedures

Prevalence: 4-24\%

DA receptors dysfunction

- Dysautonomia

Depression, anxiety, stress

- Levodopa (parafunctional chewing)

- Vitamins \& mineral (nutritional) deficiencies

- Hormonal imbalance

- Xerostomia, parafunction \& purposeless

chewing
- Discomfort (pain, sensitivity)

- Local infection (inflammation, abscess)

- Dissemination of the infection

- Mobile, and eventually loss of teeth

- Risk factor for systemic diseases (pneumonia)

- Discomfort (pain, sensitivity)

- Eating difficulties, impaired masticatory

performance

- Compromised denture retention

- Chewing disorders, eating difficulties and

self-feeding impairment

- Discomfort (pain, sensitivity)

- Speech disorders

- Social stigma (appearance \& phonetics)

- Discomfort, pain

- Dysgeusia

- Less incline to eat (weight loss)
Restore and maintain appropriate oral hygiene

Electronic toothbrushes

- Dental flossing

- Alleviate xerostomia

- Preventive dentistry with dentist visits every 4 months

- Recall dental appointments at short intervals and periodic instruction in oral health and prosthesis cleaning

- Mouth guard

- Splint therapy (bruxism)

- PD drugs adjustment (dyskinesia)

- Erosion: swish with water, enamel protection

(fluoride), avoid acidic or fizzy drinks, treatment of acid reflux

- Prosthetic rehabilitation and follow-up

- Recall dental appointments at short interval

and periodic instruction in oral health and prosthesis cleaning

- Cognitive behavioral therapy, psychotherapy, behavioral feedback

- Pramipexole

- Iron, vitamin B

- Antifungal

- Clonazepam

- Alpha-lipoic acid

requent water sipping and artificial saliva substitute, water-based denture products

AB, awake bruxism; BMS, burning mouth syndrome; BTX, botulinum toxin; CNS, central nervous system; DA, dopaminergic; L-dopa, levodopa; MAO-B, monoamine oxidase-B; PD, Parkinson's disease; SB, sleep bruxism. 
Poorly cleaned dentures $[71,78]$ facilitate biofilm accumulation, making them a reservoir for respiratory pathogens and encouraging opportunistic oral infections [146]. The oral cavity may also act as an important reservoir of $\beta$-lactam resistance genes facilitating infections with multiple drug resistant bacteria [147]. Oromuscular dysfunction contributes to changes in the oral flora: aerobic Gram negative bacilli have been isolated in the oropharynx of a small sample of PD patients, potentially shedding light on contributing factors to aspiration pneumonia [148], aspiration of oropharyngeal bacteria being linked to pneumonia [6,149], which is the main cause of death in PD [150]. Enhanced oral hygiene interventions [151-153] may therefore be of interest in PD to mitigate the risk for aspiration and pneumonia, though evidence is still lacking at the time of our writing. Bacteriemia and infections stemming from the oral cavity are also a concern regarding the motor deterioration that may follow systemic infections and inflammation in PD [154].

Along with the increased risk of systemic diseases, periodontal diseases (gingivitis, periodontitis) induce a systemic peripheral inflammation that may contribute to oxidative stress, neurodegeneration and influence PD progression [28, 155, 156]. However, the extent of it needs to be prospectively explored [81].

Finally and yet importantly, delivery systems targeting the mucosa of the oral cavity [157-159] for administering PD drugs have been investigated (piribedil [160]), are under development (ropinirole [161], levodopa/carbidopa or selegiline [162]) or have recently reached the market (apomorphine [163]). As the integrity of the oral mucosa influence the extent of drug absorption [159], oral health disorders definitely need to be addressed.

\section{THE NEUROLOGIST'S ROLE IN SUPPORTING SUCCESSFUL PREVENTION, MANAGEMENT, AND FOLLOW-UP ORAL HEALTH STRATEGIES}

Oral and dental "problems caused by PD are accentuated by physicians' lack of dental knowledge and dentists' lack of awareness of many of the oral implications of PD" [88]. However, oral diseases are largely preventable (Table 3 ) even in vulnerable populations $[22,88]$. The maintenance of the oral health of PD patients should be of prime importance in providing complete health care $[21,88]$. Initial steps have been recently taken, with the publication of clinical practice guidelines [18], although evidence-based recommendations are still scarce [15]. As dentists and dental hygienists play an integral role in providing health care to PD patients, they must be involved as early and often as possible [18, 21, 28, 86, 88].

As PD experts, neurologists and PD nurses have a major role in initiating integrated care cooperation (Fig. 4). They should coordinate appropriate, continuous, individualized, either pharmacological or non-pharmacological interventions and follow-up that target oral health. This should be done through regular patient referral to the other members of the interdisciplinary [19] team: dentists, dental hygienists, community pharmacists, nutritionists/dieticians and speech therapists [20,21, 164-166]. Due to the progressive nature of $\mathrm{PD}$, early and preventive interventions are necessary. Dental input should be requested at a very early stage, ideally immediately after initial PD diagnosis, to favor prompt and comprehensive interventions, including restorative procedures if needed, and prevent further complications [18, 28, 143]. Periodontally compromised teeth should be evaluated and endodontic treatment considered, as later infection may affect patients' motor state and response to PD treatment [154]. A conservative approach may be more appropriate in later stages of PD, considering patients' increased disability in tolerating longer appointments, performing oral hygiene maneuvers and making medical decisions as the disease progresses $[18,28,83]$. Treatment plan should be realistic, collaborative, and continuous with routine prophylaxis and regular visits, ideally 3 to 4 times a year. Interventions should be tailored to the patient's immediate and long-term dental needs. They should take into account concomitant medications (Table 2), medical prognosis, homecare abilities and settings, as well as psychosocial dimensions (anxiety, cosmetics needs), with input from the neurologist [18, 28, 83, 86, 88, 167]. Dental appointments should be as brief and as comfortable as possible, with an empathetic approach, and an understanding of PD specificities and limitations $[18,108]$. Table 4 summarizes recommendations for building PD-suited dental appointments, which can be discussed between the dental and the movement disorders teams.

To improve oral hygiene and comfort, appropriate oral healthcare tools (electric toothbrushes) and symptom-relieving products (gels, sprays) are available, and patients choice should be guided by inputs from his dental team and pharmacist $[3,165]$. PD patients and their caregivers should be educated and 


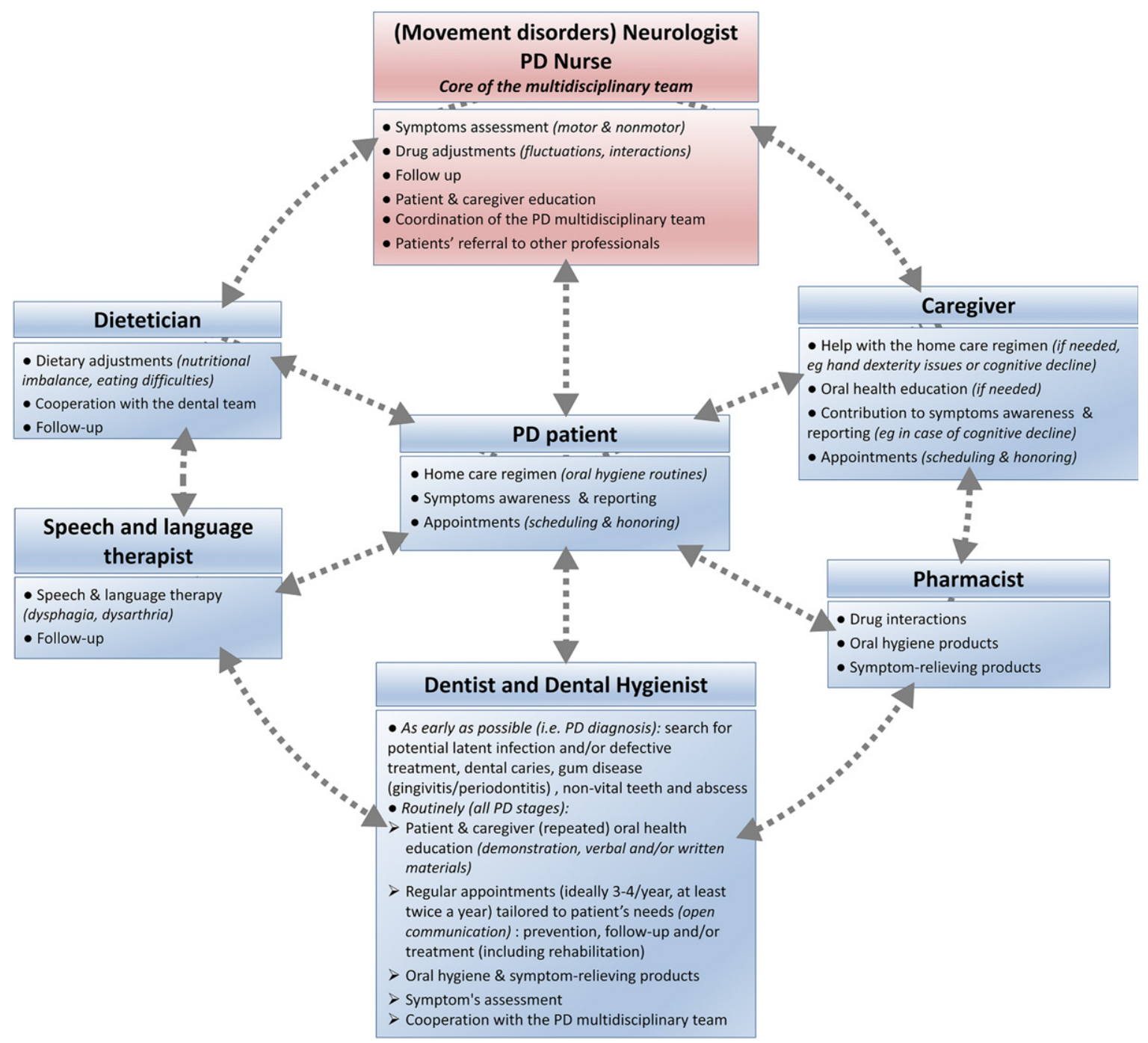

Fig. 4. Addressing oral health disorders in Parkinson's disease: An integrated care approach, coordinated by the movement disorders team (neurologist and PD nurse).

motivated to maintain good oral hygiene routines at home, by both the dental and movement disorders teams $[18,21,88]$. Live demonstrations, verbal and written repeated instructions, and positive reinforcement are effective in PD [78, 136]. By contributing to a better oral health, they decrease the risk of local and general complications- thus reducing the associated health care costs [6].

\section{FUTURE DIRECTIONS AND AREAS FOR FURTHER STUDY}

To provide holistic care, clinicians must understand the overlap between neurology, internal medicine [168] and dentistry in PD. As previously mentioned, oral health education and interdisciplinary cooperation are all initiatives that favor patients' autonomy and would therefore be empowering. The under-reporting of oral health disorders may be partly due to anosognosia. However, the fact that clinicians (neurologist and dentist alike) do not focus on these disorders certainly contributes to such issue [3]. This could be due to a lack of awareness, diagnostic criteria, and available routine screening tools, which need to be properly addressed.

\section{Towards better oral health awareness in PD}

Promotion of oral health awareness must be put on the agenda of movement disorders teams. Dentistry 
Table 4

Prevention and management strategies at the dental office: advices from the neurologist to the dental team $[3,18,21,26,68,78,79,86,102,106$, $108,115,136,245-248]$

Parkinson's disease (PD) specificities (symptoms, risks \& specific needs)

General comments

Accessibility

Communication issues

- Cognitive disorders and dementia

- Reduced non-verbal communication (facial expression, hand gesture)

- Speech and language disorders

Medical/surgical interactions

Autonomic dysfunction

Dysphagia

Neuropsychiatric disorders opening
Prevention and management strategies

- Education \& training (i.e., PD rounds/students, courses/students \& continuing medical education) to enhance PD knowledge and interdisciplinary cooperation

- Consult with the neurologist to identify PD stage (cognitive status, disease prognosis) and drug regimens

- Tailor the appointments to patient's specific condition (fluctuations and drug regimens)

- Advise:

- Oral hygiene/home care program with appropriate oral healthcare tools

- Symptom-relieving products (with the help of pharmacist if needed),

- Home training program

- Ensure repeated oral health education

- Ensure accessibility to the dental office (steps \& lifts/cane, walker, wheelchair)

- Provide assistance to get in and out of the dental chair (if needed)

- Identify the underlying type of issue

- Face-to-face communication (eye contact) in a quiet room, with no or limited background noise

- Use closed-ended questions (yes/no), simple words \& short sentences

- Allow adequate time for the patient to respond (slower response rate)

- Use visual aids and written materials if needed

- Allow caregiver's presence beside next to the operating chair (may help interpreting the patient's speech) -but do not ignore the patient by talking only to the caregiver

- Referral to speech and language therapy if needed

- Take a detailed medical history before any dental treatment (overall health, allergies, medical diagnosis, up-to-date list of medications, history of any surgeries)

- Consult with the neurologist/physician and pharmacist if needed

- In case of sedation, consider using a slower titration regime

- Look for a history of deep brain stimulation (DBS): diathermy and electrocautery may cause thermic neural lesion

Postural hypotension - If possible, vital signs (blood pressure, heart rate, pulse) measurements on every (risk of falls) visit

- Provide assistance to get in and out of the dental chair (if needed)

- Allow adequate time for the patient to change position, raise the chair slowly to the upright position

Urinary incontinence - Ensure that washrooms are accessible within the dental office

- Advice patients to empty their bladder before beginning any dental procedure

- Tailor the appointments to each patient condition

- Quiet room, stress-free environment (stress may exacerbate motor symptoms)

- Plan a series of brief office visits rather than few long visits (more realistic \& more productive): short ( $<45 \mathrm{~min}$ ), early or mid-morning appointments, $60-90$ minutes after PD drugs intake ("Best ON")

- Adjustment to the chair and interruption of dental treatment if needed (tremors, dyskinesia)

- Dental chair inclined at 30-45 degrees to facilitate the swallowing (adjust if needed to avoid aspiration)

- Use of dental rubber dam

- Adapt the use of the aspirator tip to patient's saliva characteristics (quality, quantity)

- Allow regular breaks during treatment

- Tilt head to one side (pooling in cheek)

Reduced mouth

- Use of extraoral ratchet-type mouth prop and intraoral rubber bite block

- Consult with the neurologist to adjust PD medication if needed (fluctuations)

- Home training program: jaw opening and lip and chewing exercises

- Self-identification, smile, direct eye contact and gentle touch

- Patients should always be treated by the same dentist

- Explain each step of the procedure before performing them

- Regularly reassure \& consult the patient for any discomfort

- Allow caregiver's presence beside next to the operating chair

- Good time management (avoid the sense of rushing)

- Use anxiety/stress (non-)pharmacological reduction techniques (if needed) 
Table 4

(Continued)

\begin{tabular}{ll}
\hline $\begin{array}{c}\text { Parkinson's disease (PD) specificities } \\
\text { (symptoms, risks \& specific needs) }\end{array}$ & Prevention and management strategies \\
\hline Cognitive deficits, & - Make sure to get appropriate consent \\
dementia & - Patients should always be treated by the same dentist. \\
- Compassionate, stress-free and caring environment. \\
- Use simple words \& short sentences \\
- Allow caregiver's presence beside next to the operating chair (stress, \\
communication) \\
- Limit the use of face mask (stress/anxiety) \\
- Use the VERA framework for communication: Validate the person, Emotional \\
context, Reassurance, Activity \\
- Prevention: \\
- Patients should not be treated in the supine position but in a more vertical \\
position ( $\geq 30-45$ degrees) \\
- Four-handed dentistry \\
- Use of rubber dental dams or (small) gauze screens (to protect the oropharynx) \\
or use clasps with floss if needed (small-sized objects should be secured with \\
procedure & dental floss to secure and aid retrieval) \\
& - Aggressive oral suctioning (in case of dysphagia) \\
& - Use smaller amounts of water and reduced flow during procedures \\
- Management: immediate emergency care, bronchoscopy
\end{tabular}

DBS, deep brain surgery; PD, Parkinson's disease.

should be integrated into PD course of care, alongside neurology and other medical consultations [21]. It is probable that patients would be more active in searching for access to oral care if they were aware of the link between oral and systemic health [169]. Awarenessraising actions involving movement disorders teams, dental teams and PD patients' associations are to be carried out.

Regarding clinicians' education, oral health modules developed in cooperation with dentistry schools and targeted to neurologists and PD nurses should be considered, as previous experiences of integrating such educational programs into the medical curriculum were positively received [170-172]. In order to enhance knowledge of PD oral and general specificities and limitations, dental students should join PD rounds in teaching hospitals whenever possible [21]. PD modules [173] targeted to educate dental students and update oral health professionals on caring for PD patients should also be created and routinely implemented. This would increase the cooperation between dentists and neurologists.

\section{Towards better assessment and care}

The oral health deserves more attention in PD than a sole assessment of dysphagia, sialorrhea and dysarthria. To overcome the limitations of the MDSUPDRS scale as a measurement of PD orofacial symptoms [75, 174], there is a need for better tools and questionnaires assessing all the oral symptoms associated with PD that could be used routinely by the neurologist and dental teams [3, 173]. Fully addressing these disorders is a first step for offering optimal treatment $[41,66]$.

In general, patients and caregivers should be encouraged to be aware of oral symptoms and to report them during consultations. Specific PD patient-rated assessments of discomfort and oral health impact on quality of life should also be developed, to favor symptoms reporting during dental and neurology consults.

The recently published guidelines [18] and this paper are a frame for designing PD-suited dental appointments (Table 4). However, it is critical to keep in mind that dental care, follow-up, and treatment should be patient-specific: PD stage, (non)motor features, comorbidities, medications and psychosocial factors are all to be considered. Successful cases of tailored rehabilitation have been described in the literature [58, 102, 106, 108, 109, 175-179]; this should encourage clinicians to engage in individualized treatment plans, even in complex cases. Home training and oral hygiene programs can be easily implemented and were proved to be successful [136]. Such programs must be broadly offered and can include training of jaw mobility and masticatory function, lip and cheek muscles, as well as use of special toothbrush, denture brush, interdental brush and flossing. Finally, home visiting dental services [180-182] for dental check-up and education could help tackle PD patients' difficulties in receiving those 
services at dental clinics. Domiciliary professional oral care [183], with regular professional toothbrushing $[184,185]$ could improve the quality of oral hygiene and may contribute to better nutritional status and quality of life, although this has yet to be demonstrated in cohorts of PD patients.

\section{Towards better understanding of the mechanisms involved}

The lack of methodologically sound studies in the field of neurology in relation to dentistry needs to be corrected [41]. Longitudinal studies with larger samples and standardized assessments are needed to further explore the relationship and pathophysiology of oral health disorders associated with PD $[1,4,27$, $28,41,72,94,186]$.

It has recently been demonstrated in vivo that periodontal inflammation exacerbates gut inflammation [123, 187]. The connection between the oral mucosa and the gut ("oral-gut axis") therefore needs to be investigated in PD, particularly considering the growing concerns regarding the role of the gut-brain axis and gut microbiota in promoting (neuro)inflammation [188], alpha-synuclein pathology [189-191], motor impairments [190, 192] and impairing levodopa metabolism [193-196]. Similarly, Porphyromonas gingivalis a keystone pathogen in periodontitis, along with Treponema denticola, have recently been associated with Alzheimer's disease and PD, suggesting a possible bacterial involvement in the development and course of neurodegenerative disorders [197, 198]. Poor oral health and periodontitis have indeed been associated with an increased risk of developing PD later in life in several recent studies [127, 156, 199-201] whereas dental scaling was associated with a decreased risk [202], pointing towards a "multiple-hit" hypothesis [203]. Conversely, the impact of PD on oral microbiota [204], chronic inflammation, neurodegeneration and the gut brain axis need to be thoroughly explored ([81, 148], BUCCO-PARK study, NCT039653904). Taken together, these inter-connections highlight the relevance of an "oral-gut-brain" axis that needs to be further explored.

Microbiota on dentures or in weakened oral cavity needs to be evaluated as a potential reservoir for respiratory multiple drug resistant pathogens in PD patients $[3,30,76,78,146]$. Additionally, the effect of antiparkinsonian drugs (drug class and levodopa

\footnotetext{
${ }^{4}$ https://clinicaltrials.gov/ct2/show/NCT03965390
}

equivalent daily dose, Table 2) on the oral ecosystem needs to be better characterized.

\section{Towards new diagnostic and predictive tools: Landmark symptoms and biomarkers?}

The chronology and combination of orofacial symptoms may give insights into disease progression [3, 25, 48]. The Swedish "Jönköping Parkinson Registry" ( $N=314$ idiopathic PD patients, prospective study led between 1998 and 2014) has recently highlighted that orofacial symptoms were correlated with PD severity, symmetry of motor disturbances, and autonomic disorders. The more severe orofacial burden was at baseline, the faster patients progressed to more advanced stages [25]. As stated earlier, some orofacial symptoms occurs early in the disease course (hyposmia [31], hyposialorrhea [33], tongue tremor [34-36], upper-body axial symptoms [37]), whereas others are more apparent and frequent in advanced stages (dysphagia, drooling). Considering that only a few of these disorders have been thoroughly assessed in PD, more longitudinal studies with larger stratified samples are needed to further explore their predictive value. A recent Korean nationwide population-based cohort study has thus suggested that an increased number of missing teeth may be an important risk indicator of new-onset PD [205].

Identifying reliable biomarkers is of crucial importance in PD, particularly regarding the potential development of neuroprotective treatment strategies. Readily accessible, saliva allows non-invasive and convenient sampling for proteomic analysis in PD [206, 207]. Altered expression of $\alpha$-synuclein, DJ1 protein and microRNAs have been reported in the saliva of PD patients. They could become promising biomarkers for PD severity and differential diagnosis [206-212]. Correlating such peripheral biomarkers with the emergence and severity of clinical signs would be a further asset: a decrease in substance P saliva levels has been associated with early dysphagia [213]. Biopsies of the submandibular gland to detect pathological $\alpha$-synuclein [214-216] may also hold promises, though such findings need to be supported by larger cohorts.

Finally, the oral microbiota may offer new insights into the pathophysiology of $\mathrm{PD}[81,82]$, with a probable evolution of its composition throughout the course of the disease. A recent report suggests correlations between oral microbiota alterations and functional changes (cognition and balance) in early stage PD [81]. The currently undergoing BUCCO-PARK study 
(NCT03965390) is expected to provide longitudinal data of a cohort of 50 French PD patients in a prospective manner. Similarly to other diseases [217-220], future studies may even be able to identify microbiota signature associated with disease severity, clinical symptoms or PD medications in the future. Additionally, the possible interplay between the oral, nasal and gut microbiota demand further attention [82, 221-223].

\section{CONCLUSION}

Though closely located, the central nervous system and oral cavity are rarely assessed together. In PD, orofacial manifestations overlap neurology and dentistry, with direct and indirect impact on patients' general well-being and quality of life, regardless of disease stage. There is still much to do to: 1) improve oral health awareness among medical professionals, patients and caregivers [169] and develop efficient interdisciplinary cooperation [166], 2) specifically assess and treat oral health disorders in PD patients, 3) understand the pathophysiological and chronological mechanisms underlying these disorders, and 4) determine whether the oral cavity may become an easy access valuable tool for diagnosis and prognosis. As a whole, neurologists should be aware of the clinical implications of oral health disorders in PD and should initiate and coordinate integrated care. On their own, dentists need to get more involved into the care of PD patients and adjust to a personalized approach for patient-specific needs. Familiarizing neurologists and dentists with oral health disorders in PD is critical for better recognition, diagnosis, and correct decision upon treatment. The consideration of the interplay between oral and general health is crucial to understand what is at stake for PD patients. Early, proactive, and preventive interventions are necessary to avoid reactive care stemming from oral and dental diseases accumulation. Of course, many of these statements apply to other neurological diseases involving cognitive or movement disorders, such as Alzheimer's disease, multiple sclerosis, or Huntington's disease. This paper therefore advocates to end the neglect of oral health in neurology, and to address the general paucity of strong literature. Considering the two-way relationship between oral and general health, and underlying multimorbidity, it is time to bridge the gap between neurology and dentistry, avoiding single provider tunnel vision and siloed care by working in concert towards patients' overall health.

\section{ACKNOWLEDGMENTS}

The authors would like to thank Shao Bing Fong $(\mathrm{PhD}$, The University of Melbourne) for proofreading the manuscript. The authors also wish to thank France Parkinson for supporting the BUCCOPARK project. Finally, MV and MA wish to thank France Développement Electronique (FDE) for its continued support and Homeperf for covering the expenses related to the presentation of this work at the 71st American Academy of Neurology meeting.

This research did not receive any specific grant from funding agencies in the public, commercial, or not-for-profit sectors.

\section{CONFLICT OF INTEREST}

The authors declare that there are no conflicts of interest relevant to this work.

France Parkinson (a French Parkinson's disease Association) financially supports the BUCCO-PARK clinical trial (Rennes, France -ClinicalTrials.gov Identifier: NCT03965390), an interdisciplinary research project based on some of the findings summarized in this paper.

\section{PUBLICATION HISTORY}

The intention and preliminary results of this review project have been presented as a poster at the 71st American Academy of Neurology (AAN) meeting in Philadelphia, USA on May 2019: Manon Auffret, Vincent Meuric, Emile Boyer, Martine Bonnaure-Mallet, Marc Verin. Oral cavity disorders in Parkinson's disease: more than meets the eye (P5.8-038). Neurology Apr 2019, 92 (15 Supplement) P5.8-038. https://n.neurology.org/content/92/15_Sup plement/P5.8-038

\section{SUPPLEMENTARY MATERIAL}

The supplementary material is available in the electronic version of this article: https://dx.doi.org/ 10.3233/JPD-212605.

\section{REFERENCES}

[1] Fereshtehnejad S-M, Garcia-Ptacek S, Religa D, Holmer J, Buhlin K, Eriksdotter M, Sandborgh-Englund G (2018) Dental care utilization in patients with different types of dementia: A longitudinal nationwide study of 58,037 individuals. Alzheimers Dement 14, 10-19. 
[2] Lauritano D, Moreo G, Carinci F, Borgia R, Lucchese A, Contaldo M, Della Vella F, Bernardelli P, Moreo G, Petruzzi M (2019) Aging and oral care: An observational study of characteristics and prevalence of oral diseases in an Italian cohort. Int J Environ Res Public Health 16, 3763.

[3] Barbe AG, Bock N, Derman SHM, Felsch M, Timmermann L, Noack MJ (2017) Self-assessment of oral health, dental health care and oral health-related quality of life among Parkinson's disease patients. Gerodontology 34, 135-143.

[4] Ribeiro GR, Campos CH, Garcia RCMR, Ribeiro GR, Campos CH, Garcia RCMR (2016) Oral health in elders with Parkinson's disease. Braz Dental J 27, 340-344.

[5] van Stiphout MAE, Marinus J, van Hilten JJ, Lobbezoo F, de Baat C (2018) Oral health of Parkinson's disease patients: A case-control study. Parkinsons Dis 2018, 9315285.

[6] Bui FQ, Almeida-da-Silva CLC, Huynh B, Trinh A, Liu J, Woodward J, Asadi H, Ojcius DM (2019) Association between periodontal pathogens and systemic disease. Biomed J 42, 27-35.

[7] de Andrade FB, Lebrão ML, Santos JLF, da Cruz Teixeira DS, de Oliveira Duarte YA (2012) Relationship between oral health-related quality of life, oral health, socioeconomic, and general health factors in elderly Brazilians. $J$ Am Geriatr Soc 60, 1755-1760.

[8] Holmstrup P, Damgaard C, Olsen I, Klinge B, Flyvbjerg A, Nielsen CH, Hansen PR (2017) Comorbidity of periodontal disease: Two sides of the same coin? An introduction for the clinician. J Oral Microbiol 9, 1332710.

[9] Lauritano D, Lo Muzio L, Gaudio RM, Lo Russo L, Mucchi D, Nardi GM, Scapoli L (2016) The ecological catastrophe of oral diseases: A possible link between periodontitis and protozoa. J Biol Regul Homeost Agents 30, 143-147.

[10] Peres MA, Macpherson LMD, Weyant RJ, Daly B, Venturelli R, Mathur MR, Listl S, Celeste RK, GuarnizoHerreño CC, Kearns C, Benzian H, Allison P, Watt RG (2019) Oral diseases: A global public health challenge. Lancet 394, 249-260.

[11] Del Rey NL-G, Quiroga-Varela A, Garbayo E, CarballoCarbajal I, Fernández-Santiago R, Monje MHG, TrigoDamas I, Blanco-Prieto MJ, Blesa J (2018) Advances in Parkinson's disease: 200 years later. Front Neuroanat 12, 113.

[12] Klingelhoefer L, Reichmann H (2017) Parkinson's disease as a multisystem disorder. J Neural Transm 124, 709-713.

[13] Titova N, Padmakumar C, Lewis SJG, Chaudhuri KR (2017) Parkinson's: A syndrome rather than a disease? J Neural Transm (Vienna) 124, 907-914.

[14] Schapira AHV, Chaudhuri KR, Jenner P (2017) Nonmotor features of Parkinson disease. Nat Rev Neurosci 18, 435-450.

[15] Seppi K, Ray Chaudhuri K, Coelho M, Fox SH, Katzenschlager R, Perez Lloret S, Weintraub D, Sampaio C, the collaborators of the Parkinson's Disease Update on NonMotor Symptoms Study Group on behalf of the Movement Disorders Society Evidence-Based Medicine Committee (2019) Update on treatments for nonmotor symptoms of Parkinson's disease-an evidence-based medicine review. Mov Disord 34, 180-198.

[16] Bellomo R, Bagshaw SM (2006) Evidence-based medicine: Classifying the evidence from clinical trials the need to consider other dimensions. Crit Care 10, 232.
[17] Batista LM, Portela de Oliveira MT, Magalhaes WB, Bastos PL (2015) Oral hygiene in patients with Parkinson's disease. R I Med J (2013) 98, 35-37.

[18] Gosnell R, Lazear J, Hemphill JC, Dotson D (2019) Development of guidelines for improving oral health in individuals with Parkinson's disease. Gerodontology 36, 229-235.

[19] Rajan R, Brennan L, Bloem BR, Dahodwala N, Gardner J, Goldman JG, Grimes DA, Iansek R, Kovács N, McGinley J, Parashos SA, Piemonte MEP, Eggers C (2020) Integrated care in Parkinson's disease: A systematic review and meta-analysis. Mov Disord 35, 15091531.

[20] Radder DLM, de Vries NM, Riksen NP, Diamond SJ, Gross D, Gold DR, Heesakkers J, Henderson E, Hommel ALAJ, Lennaerts HH, Busch J, Dorsey RE, Andrejack J, Bloem BR (2019) Multidisciplinary care for people with Parkinson's disease: The new kids on the block! Expert Rev Neurother 19, 145-157.

[21] Rozas NS, Sadowsky JM, Jones DJ, Jeter CB (2017) Incorporating oral health into interprofessional care teams for patients with Parkinson's disease. Parkinsonism Relat Disord 43, 9-14.

[22] Haag DG, Peres KG, Balasubramanian M, Brennan DS (2017) Oral conditions and health-related quality of life: A systematic review. J Dent Res 96, 864-874.

[23] Petersen PE, Bourgeois D, Ogawa H, Estupinan-Day S, Ndiaye C (2005) The global burden of oral diseases and risks to oral health. Bull World Health Organ 83, 661-669.

[24] Petersen PE, Baehni PC (2012) Periodontal health and global public health. Periodontol 2000 60, 7-14.

[25] Fereshtehnejad S-M, Skogar Ö, Lökk J (2017) Evolution of orofacial symptoms and disease progression in idiopathic Parkinson's disease: Longitudinal data from the Jönköping Parkinson Registry. Parkinsons Dis 2017, 7802819.

[26] Friedlander AH, Mahler M, Norman KM, Ettinger RL (2009) Parkinson disease: Systemic and orofacial manifestations, medical and dental management. J Am Dent Assoc 140, 658-669.

[27] Hanaoka A, Kashihara K (2009) Increased frequencies of caries, periodontal disease and tooth loss in patients with Parkinson's disease. J Clin Neurosci 16, 1279-1282.

[28] Müller T, Palluch R, Jackowski J (2011) Caries and periodontal disease in patients with Parkinson's disease. Spec Care Dentist 31, 178-181.

[29] Fukayo S, Nonaka K, Shimizu T, Yano E (2003) Oral health of patients with Parkinson's disease: Factors related to their better dental status. Tohoku J Exp Med 201, 171-179.

[30] Persson M, Osterberg T, Granérus AK, Karlsson S (1992) Influence of Parkinson's disease on oral health. Acta Odontol Scand 50, 37-42.

[31] Goldman JG, Postuma R (2014) Premotor and non-motor features of Parkinson's disease. Curr Opin Neurol 27, 434-441.

[32] Siderowf A, Jennings D, Eberly S, Oakes D, Hawkins KA, Ascherio A, Stern MB, Marek K, PARS Investigators (2012) Impaired olfaction and other prodromal features in the Parkinson At-Risk Syndrome Study. Mov Disord 27, 406-412.

[33] Cersósimo MG, Tumilasci OR, Raina GB, Benarroch EE, Cardoso EM, Micheli F, Pazo JH (2009) Hyposialorrhea as an early manifestation of Parkinson disease. Auton Neurosci 150, 150-151. 
[34] Delil Ş, BölükbaşıF, Yeni N, Kızıltan G (2015) Reemergent tongue tremor as the presenting symptom of Parkinson's disease. Balkan Med J 32, 127-128.

[35] Fabbri M, Abreu L, Santos T, Ferreira JJ (2017) Resting and reemergent tongue tremor as presenting symptoms of Parkinson's disease. Mov Disord Clin Pract 4, 273-274.

[36] Jaulent P, Laurencin C, Robert H, Thobois S (2015) Parkinson's disease revealed by a resting tongue tremor. $\mathrm{Mov}$ Disord Clin Pract 2, 432-433.

[37] Moreau C, Devos D, Baille G, Delval A, Tard C, Perez T, Danel-Buhl N, Seguy D, Labreuche J, Duhamel A, Delliaux M, Dujardin K, Defebvre L (2016) Are upper-body axial symptoms a feature of early Parkinson's disease? PLoS One 11, e0162904.

[38] Noyce AJ, Silveira-Moriyama L, Gilpin P, Ling H, Howard R, Lees AJ (2012) Severe dysphagia as a presentation of Parkinson's disease. Mov Disord 27, 457-458.

[39] Owolabi LF, Samaila AA, Sunmonu T (2014) Gastrointestinal complications in newly diagnosed Parkinson's disease: A case-control study. Trop Gastroenterol 35, 227-231.

[40] Simonet C, Schrag A, Lees AJ, Noyce AJ (2021) The motor prodromes of Parkinson's disease: From bedside observation to large-scale application. J Neurol 268, 20992108.

[41] Perez-Lloret S, Nègre-Pagès L, Ojero-Senard A, Damier P, Destée A, Tison F, Merello M, Rascol O, COPARK Study Group (2012) Oro-buccal symptoms (dysphagia, dysarthria, and sialorrhea) in patients with Parkinson's disease: Preliminary analysis from the French COPARK cohort. Eur J Neurol 19, 28-37.

[42] Politis M, Wu K, Molloy S, G Bain P, Chaudhuri KR, Piccini $\mathrm{P}$ (2010) Parkinson's disease symptoms: The patient's perspective. Mov Disord 25, 1646-1651.

[43] Patel B, Legacy J, Hegland KW, Okun MS, Herndon NE (2020) A comprehensive review of the diagnosis and treatment of Parkinson's disease dysphagia and aspiration. Expert Rev Gastroenterol Hepatol 14, 411-424.

[44] Suttrup I, Warnecke T (2016) Dysphagia in Parkinson's disease. Dysphagia 31, 24-32.

[45] Brabenec L, Mekyska J, Galaz Z, Rektorova I (2017) Speech disorders in Parkinson's disease: Early diagnostics and effects of medication and brain stimulation. J Neural Transm (Vienna) 124, 303-334.

[46] Moreau C, Pinto S (2019) Misconceptions about speech impairment in Parkinson's disease. Mov Disord 34, 14711475.

[47] van Wamelen DJ, Leta V, Johnson J, Ocampo CL, Podlewska AM, Rukavina K, Rizos A, Martinez-Martin P, Chaudhuri KR (2020) Drooling in Parkinson's disease: Prevalence and progression from the Non-motor International Longitudinal Study. Dysphagia 35, 955-961.

[48] Bakke M, Larsen SL, Lautrup C, Karlsborg M (2011) Orofacial function and oral health in patients with Parkinson's disease. Eur J Oral Sci 119, 27-32.

[49] Chen Y-Y, Fan H-C, Tung M-C, Chang Y-K (2019) The association between Parkinson's disease and temporomandibular disorder. PLoS One 14, e0217763.

[50] Donizetti Verri E, da Silva GP, Marianetti Fioco E, Soares da Silva N, Valin Fabrin SC, Augusto Bueno Zanella C, Roberta Garrefa C, Faria Júnior M, Siéssere S, Hallak JEC, Palinkas M, Chaves TC, Regalo SCH (2019) Effects of Parkinson's disease on molar bite force, electromyographic activity and muscle thickness of the masseter, temporal and sternocleidomastoid muscles: A case-control study. J Oral Rehabil 46, 912-919.

[51] Minagi S, Matsunaga T, Shibata T, Sato T (1998) An appliance for management of TMJ pain as a complication of Parkinson's disease. CRANIO® 16, 57-59.

[52] Ribeiro GR, Campos CH, Rodrigues Garcia RCM (2017) Parkinson's disease impairs masticatory function. Clin Oral Investig 21, 1149-1156.

[53] Robertson LT, Hammerstad JP (1996) Jaw movement dysfunction related to Parkinson's disease and partially modified by levodopa. J Neurol Neurosurg Psychiatry 60, 41-50.

[54] Verhoeff MC, Lobbezoo F, Wetselaar P, Aarab G, Koutris M (2018) Parkinson's disease, temporomandibular disorders and bruxism: A pilot study. J Oral Rehabil 45, 854-863.

[55] Pahwa R, Isaacson S, Jimenez-Shaheed J, Malaty IA, Deik A, Johnson R, Patni R (2019) Impact of dyskinesia on activities of daily living in Parkinson's disease: Results from pooled phase 3 ADS-5102 clinical trials. Parkinsonism Relat Disord 60, 118-125.

[56] Miranda M, Chaná P (2000) Severe off-period facial dystonia in Parkinson's disease. Mov Disord 15, 163-164.

[57] Moreau C, Ozsancak C, Blatt J-L, Derambure P, Destee A, Defebvre L (2007) Oral festination in Parkinson's disease: Biomechanical analysis and correlation with festination and freezing of gait. Mov Disord 22, 1503-1506.

[58] Durham TM, Hodges ED, Henry MJ, Geasland J, Straub P (1993) Management of orofacial manifestations of Parkinson's disease with splint therapy: A case report. Spec Care Dentist 13, 155-158.

[59] Samura K, Miyagi Y, Morioka T, Murakami N, Yoshida F, Hashiguchi K, Sakae N, Yamasaki R, Kawaguchi M, Nagata S, Sasaki T (2008) Intractable facial pain in advanced Parkinson's disease alleviated by subthalamic nucleus stimulation. J Neurol Neurosurg Psychiatry 79, 1410-1411.

[60] Haehner A, Masala C, Walter S, Reichmann H, Hummel T (2019) Incidence of Parkinson's disease in a large patient cohort with idiopathic smell and taste loss. J Neurol 266, 339-345.

[61] Kashihara K, Hanaoka A, Imamura T (2011) Frequency and characteristics of taste impairment in patients with Parkinson's disease: Results of a clinical interview. Intern Med 50, 2311-2315.

[62] Masala C, Loy F, Piras R, Liscia A, Fadda L, Moat A, Solla P, Defazio G (2020) Effect of olfactory and gustatory dysfunction and motor symptoms on body weight in patients with Parkinson's disease. Brain Sci 10, 218.

[63] Oppo V, Melis M, Melis M, Tomassini Barbarossa I, Cossu G (2020) "Smelling and tasting" Parkinson's disease: Using senses to improve the knowledge of the disease. Front Aging Neurosci 12, 43.

[64] Shah M, Deeb J, Fernando M, Noyce A, Visentin E, Findley LJ, Hawkes CH (2009) Abnormality of taste and smell in Parkinson's disease. Parkinsonism Relat Disord 15, 232-237.

[65] Ella B, Ghorayeb I, Burbaud P, Guehl D (2017) Bruxism in movement disorders: A comprehensive review. $J$ Prosthodont 26, 599-605.

[66] Zlotnik Y, Balash Y, Korczyn AD, Giladi N, Gurevich $\mathrm{T}$ (2015) Disorders of the oral cavity in Parkinson's disease and parkinsonian syndromes. Parkinsons Dis 2015, 379482 . 
[67] Bonenfant D, Rompré PH, Rei N, Jodoin N, Soland VL, Rey V, Brefel-Courbon C, Ory-Magne F, Rascol O, Blanchet PJ (2016) Characterization of burning mouth syndrome in patients with Parkinson's disease. J Oral Facial Pain Headache 30, 318-322.

[68] Cicciù M, Risitano G, Lo Giudice G, Bramanti E (2012) Periodontal health and caries prevalence evaluation in patients affected by Parkinson's disease. Parkinsons Dis 2012, 541908

[69] Clifford T, Finnerty J (1995) The dental awareness and needs of a Parkinson's disease population. Gerodontology 12, 99-103.

[70] Coon EA, Laughlin RS (2012) Burning mouth syndrome in Parkinson's disease: Dopamine as cure or cause? $J$ Headache Pain 13, 255-257.

[71] Nakayama Y, Washio M, Mori M (2004) Oral health conditions in patients with Parkinson's disease. J Epidemiol 14, 143-150.

[72] Pradeep AR, Singh SP, Martande SS, Raju AP, Rustagi T, Suke DK, Naik SB (2015) Clinical evaluation of the periodontal health condition and oral health awareness in Parkinson's disease patients. Gerodontology 32, 100-106.

[73] Anastassiadou V, Katsarou Z, Naka O, Bostanzopoulou M (2002) Evaluating dental status and prosthetic need in relation to medical findings in Greek patients suffering from idiopathic Parkinson's disease. Eur J Prosthodont Restor Dent 10, 63-68.

[74] Einarsdóttir ER, Gunnsteinsdóttir H, Hallsdóttir MH, Sveinsson S, Jónsdóttir SR, Olafsson VG, Bragason TH, Saemundsson SR, Holbrook WP (2009) Dental health of patients with Parkinson's disease in Iceland. Spec Care Dentist 29, 123-127.

[75] Lyra P, Machado V, Proença L, Domingos J, Godinho C, Mendes JJ, Botelho J (2020) Parkinson's disease, periodontitis and patient-related outcomes: A cross-sectional study. Medicina (Kaunas) 56, 383.

[76] Schwarz J, Heimhilger E, Storch A (2006) Increased periodontal pathology in Parkinson's disease. J Neurol 253, 608-611.

[77] Barbe AG, Deutscher DHC, Derman SHM, Hellmich M, Noack MJ (2017) Subjective and objective halitosis among patients with Parkinson's disease. Gerodontology 34, 460-468.

[78] Ribeiro GR, Campos CH, Garcia RCMR (2017) Removable prosthesis hygiene in elders with Parkinson's disease. Spec Care Dentist 37, 277-281.

[79] Ribeiro GR, Campos CH, Rodrigues Garcia RCM (2017) Influence of a removable prosthesis on oral health-related quality of life and mastication in elders with Parkinson disease. J Prosthet Dent 118, 637-642.

[80] Kennedy MA, Rosen S, Paulson GW, Jolly DE, Beck FM (1994) Relationship of oral microflora with oral health status in Parkinson's disease. Spec Care Dentist 14, 164-168.

[81] Mihaila D, Donegan J, Barns S, LaRocca D, Du Q, Zheng D, Vidal M, Neville C, Uhlig R, Middleton FA (2019) The oral microbiome of early stage Parkinson's disease and its relationship with functional measures of motor and non-motor function. PLoS One 14, e0218252.

[82] Pereira PAB, Aho VTE, Paulin L, Pekkonen E, Auvinen P, Scheperjans F (2017) Oral and nasal microbiota in Parkinson's disease. Parkinsonism Relat Disord 38, 61-67.

[83] Packer M, Nikitin V, Coward T, Davis DM, Fiske J (2009) The potential benefits of dental implants on the oral health quality of life of people with Parkinson's disease. Gerodontology 26, 11-18.

[84] Becker DE (2011) Adverse drug interactions. Anesth Prog 58, 31-41.

[85] Chiu SY, Tsuboi T, Hegland KW, Herndon NE, Shukla AW, Patterson A, Almeida L, Foote KD, Okun MS, Ramirez-Zamora A (2020) Dysarthria and speech intelligibility following Parkinson's disease globus pallidus internus deep brain stimulation. J Parkinsons Dis 10, 1493 1502 .

[86] DeBowes SL, Tolle SL, Bruhn AM (2013) Parkinson's disease: Considerations for dental hygienists. Int J Dent Hyg 11, 15-21.

[87] Illi A, Sundberg S, Ojala-Karlsson P, Korhonen P, Scheinin M, Gordin A (1995) The effect of entacapone on the disposition and hemodynamic effects of intravenous isoproterenol and epinephrine. Clin Pharmacol Ther 58, 221-227.

[88] Jolly DE, Paulson RB, Paulson GW, Pike JA (1989) Parkinson's disease: A review and recommendations for dental management. Spec Care Dentist 9, 74-78.

[89] Klietz M, Greten S, Wegner F, Höglinger GU (2019) Safety and tolerability of pharmacotherapies for Parkinson's disease in geriatric patients. Drugs Aging 36, 511-530.

[90] Lim GXD (2017) Deep Brain Stimulation: Literature review of the unseen challenges to optimal dentistry. $J$ Disabil Oral Health 18, 31-42.

[91] Maiola R, Ramirez Gómez CC, Micheli F (2016) Lingual protrusion dystonia: Manifestation during "on" periods in Parkinson's disease. J Neurol Sci 370, 256-257.

[92] Nutt JG, Anderson VC, Peacock JH, Hammerstad JP, Burchiel KJ (2001) DBS and diathermy interaction induces severe CNS damage. Neurology 56, 13841386.

[93] Prashantha DK, Pal PK (2009) Serpentine tongue: A rare manifestation following initiation of levodopa therapy in a patient with Parkinson's disease. Parkinsonism Relat Disord 15, 718-719.

[94] Tiigimäe-Saar J, Taba P, Tamme T (2017) Does Botulinum neurotoxin type A treatment for sialorrhea change oral health? Clin Oral Investig 21, 795-800.

[95] Walter DC, Barbeau A (1972) Parkinson's disease: The effect of levodopa therapy on the dentition: Report of case. $J$ Am Dent Assoc 85, 133-138.

[96] Weiner WJ, Nausieda PA (1982) Meige's syndrome during long-term dopaminergic therapy in Parkinson's disease. Arch Neurol 39, 451-452.

[97] Wertheimer J, Gottuso AY, Nuno M, Walton C, Duboille A, Tuchman M, Ramig L (2014) The impact of STN deep brain stimulation on speech in individuals with Parkinson's disease: The patient's perspective. Parkinsonism Relat Disord 20, 1065-1070.

[98] Zornberg GL, Bodkin JA, Cohen BM (1991) Severe adverse interaction between pethidine and selegiline. Lancet 337, 246.

[99] Allen NE, Schwarzel AK, Canning CG (2013) Recurrent falls in Parkinson's disease: A systematic review. Parkinsons Dis 2013, 906274.

[100] LeWitt PA, Kymes S, Hauser RA (2020) Parkinson disease and orthostatic hypotension in the elderly: Recognition and management of risk factors for falls. Aging Dis 11, 679-691.

[101] Khan I (2020) Falls: Considerations for the dental surgeon. Br Dent J 228, 509-514. 
[102] Kaka S, Lane H, Sherwin E (2019) Dentistry and Parkinson's disease: Learnings from two case reports. Br Dent $J$ 227, 30-36.

[103] Rabin ML, Earnhardt MC, Patel A, Ganihong I, Kurlan R (2016) Postural, bone, and joint disorders in Parkinson's disease. Mov Disord Clin Practice 3, 538-547.

[104] El-Yousfi S, Jones K, White S, Marshman Z (2019) A rapid review of barriers to oral healthcare for vulnerable people. Br Dent J 227, 143-151.

[105] Kiyak HA, Reichmuth M (2005) Barriers to and enablers of older adults' use of dental services. J Dent Educ 69, 975-986.

[106] Al-Omari FA, Al Moaleem MM, Al-Qahtani SS, Al Garni AS, Sadatullah S, Luqman M (2014) Oral rehabilitation of Parkinson's disease patient: A review and case report. Case Rep Dent 2014, 432475.

[107] Jablonski RA, Kolanowski A, Therrien B, Mahoney EK, Kassab C, Leslie DL (2011) Reducing care-resistant behaviors during oral hygiene in persons with dementia. BMC Oral Health 11, 30 .

[108] Haralur SB (2015) Clinical strategies for complete denture rehabilitation in a patient with Parkinson disease and reduced neuromuscular control. Case Rep Dent 2015, 352878.

[109] Heckmann SM, Heckmann JG, Weber HP (2000) Clinical outcomes of three Parkinson's disease patients treated with mandibular implant overdentures. Clin Oral Implants Res 11, 566-571.

[110] Doherty KM, van de Warrenburg BP, Peralta MC, SilveiraMoriyama L, Azulay J-P, Gershanik OS, Bloem BR (2011) Postural deformities in Parkinson's disease. Lancet Neurol 10, 538-549.

[111] Chagas MHN, Oliveira THGF, Linares IMP, Balarini FB, Chagas NMS, Tumas V, Crippa JAS (2017) Can anxiety increase tremors in patients with Parkinson's disease? An experimental model. Arch Clin Psychiatry 44, 85-88.

[112] Hunker CJ, Abbs JH (1990) Uniform frequency of parkinsonian resting tremor in the lips, jaw, tongue, and index finger. Mov Disord 5, 71-77.

[113] Numao A, Suzuki K, Fujita H, Hirata K (2017) Resting and re-emergent tongue tremor in Parkinson's disease. $B M J$ Case Rep 2017, bcr2017221808.

[114] Silverdale MA, Schneider SA, Bhatia KP, Lang AE (2008) The spectrum of orolingual tremor-a proposed classification system. Mov Disord 23, 159-167.

[115] Deliberador TM, Marengo G, Scaratti R, Giovanini AF, Zielak JC, Baratto Filho F (2011) Accidental aspiration in a patient with Parkinson's disease during implantsupported prosthesis construction: A case report. Spec Care Dentist 31, 156-161.

[116] Madan A, Ray S, Burdick D, Agarwal P (2017) Management of lower urinary tract symptoms in Parkinson's disease in the neurology clinic. Int J Neurosci 127, 11361149 .

[117] Ricciardi L, Bologna M, Morgante F, Ricciardi D, Morabito B, Volpe D, Martino D, Tessitore A, Pomponi M, Bentivoglio AR, Bernabei R, Fasano A (2015) Reduced facial expressiveness in Parkinson's disease: A pure motor disorder? J Neurol Sci 358, 125-130.

[118] Argaud S, Vérin M, Sauleau P, Grandjean D (2018) Facial emotion recognition in Parkinson's disease: A review and new hypotheses. Mov Disord 33, 554-567.

[119] Priebe JA, Kunz M, Morcinek C, Rieckmann P, Lautenbacher S (2015) Does Parkinson's disease lead to alterations in the facial expression of pain? J Neurol Sci 359, 226-235.

[120] Smith KM, Caplan DN (2018) Communication impairment in Parkinson's disease: Impact of motor and cognitive symptoms on speech and language. Brain Lang 185, 38-46.

[121] Thomas M, Lenka A, Kumar Pal P (2017) Handwriting analysis in Parkinson's disease: Current status and future directions. Mov Disord Clin Pract 4, 806-818.

[122] Dörfer C, Benz C, Aida J, Campard G (2017) The relationship of oral health with general health and NCDs: A brief review. Int Dent $J$ 67, 14-18.

[123] Hajishengallis G, Chavakis T (2021) Local and systemic mechanisms linking periodontal disease and inflammatory comorbidities. Nat Rev Immunol, doi: 10.1038/s41577. 020-00488-6

[124] Hakeem FF, Bernabé E, Sabbah W (2019) Association between oral health and frailty: A systematic review of longitudinal studies. Gerodontology 36, 205-215.

[125] Scannapieco FA, Cantos A (2016) Oral inflammation and infection, and chronic medical diseases: Implications for the elderly. Periodontol 2000 72, 153-175.

[126] Tonetti MS, Jepsen S, Jin L, Otomo-Corgel J (2017) Impact of the global burden of periodontal diseases on health, nutrition and wellbeing of mankind: A call for global action. J Clin Periodontol 44, 456-462.

[127] Hashioka S, Inoue K, Miyaoka T, Hayashida M, Wake R, Oh-Nishi A, Inagaki M (2019) The possible causal link of periodontitis to neuropsychiatric disorders: More than psychosocial mechanisms. Int J Mol Sci 20, 3723.

[128] Michaud DS, Fu Z, Shi J, Chung M (2017) Periodontal disease, tooth loss, and cancer risk. Epidemiol Rev 39, 49-58.

[129] Sadrameli M, Bathini P, Alberi L (2020) Linking mechanisms of periodontitis to Alzheimer's disease. Curr Opin Neurol 33, 230-238.

[130] Singhrao SK, Harding A, Simmons T, Robinson S, Kesavalu L, Crean S (2014) Oral inflammation, tooth loss, risk factors, and association with progression of Alzheimer's disease. J Alzheimers Dis 42, 723-737.

[131] Könönen E, Gursoy M, Gursoy UK (2019) Periodontitis: A multifaceted disease of tooth-supporting tissues. J Clin Med 8, 1135.

[132] Brennan DS, Spencer AJ, Roberts-Thomson KF (2008) Tooth loss, chewing ability and quality of life. Qual Life Res 17, 227-235.

[133] Gerritsen AE, Allen PF, Witter DJ, Bronkhorst EM, Creugers NH (2010) Tooth loss and oral health-related quality of life: A systematic review and meta-analysis. Health Qual Life Outcomes 8, 126.

[134] Roumanas ED (2009) The social solution-denture esthetics, phonetics, and function. J Prosthodont 18, 112-115.

[135] Hung H-C, Willett W, Ascherio A, Rosner BA, Rimm E, Joshipura KJ (2003) Tooth loss and dietary intake. J Am Dent Assoc 134, 1185-1192.

[136] Baram S, Karlsborg M, Bakke M (2020) Improvement of oral function and hygiene in Parkinson's disease: A randomised controlled clinical trial. J Oral Rehabil 47, 370-376.

[137] Gondivkar SM, Gadbail AR, Gondivkar RS, Sarode SC, Sarode GS, Patil S, Awan KH (2019) Nutrition and oral health. Dis Mon 65, 147-154.

[138] Cecchini MP, Fasano A, Boschi F, Osculati F, Tinazzi M (2015) Taste in Parkinson's disease. J Neurol 262, 806-813. 
[139] Umemoto G, Tsuboi Y, Kitashima A, Furuya H, Kikuta T (2011) Impaired food transportation in Parkinson's disease related to lingual bradykinesia. Dysphagia 26, 250-255.

[140] Nyholm D, Lennernäs H (2008) Irregular gastrointestinal drug absorption in Parkinson's disease. Expert Opin Drug Metab Toxicol 4, 193-203.

[141] Stillhart C, Vučićević K, Augustijns P, Basit AW, Batchelor H, Flanagan TR, Gesquiere I, Greupink R, Keszthelyi D, Koskinen M, Madla CM, Matthys C, Miljuš G, Mooij MG, Parrott N, Ungell A-L, de Wildt SN, Orlu M, Klein S, Müllertz A (2020) Impact of gastrointestinal physiology on drug absorption in special populations-An UNGAP review. Eur J Pharm Sci 147, 105280.

[142] Lorefält B, Granérus A-K, Unosson M (2006) Avoidance of solid food in weight losing older patients with Parkinson's disease. J Clin Nurs 15, 1404-1412.

[143] Fiske J, Hyland K (2000) Parkinson's disease and oral care. Dent Update 27, 58-65.

[144] Travers JB, Akey LR, Chen SC, Rosen S, Paulson G, Travers SP (1993) Taste preferences in Parkinson's disease patients. Chem Senses 18, 47-55.

[145] Garcia JM, Chambers EI (2010) Managing dysphagia through diet modifications. Am J Nurs 110, 26-33.

[146] O'Donnell LE, Smith K, Williams C, Nile CJ, Lappin DF, Bradshaw D, Lambert M, Robertson DP, Bagg J, Hannah V, Ramage G (2016) Dentures are a reservoir for respiratory pathogens. J Prosthodont 25, 99-104.

[147] Dupin C, Tamanai-Shacoori Z, Ehrmann E, Dupont A, Barloy-Hubler F, Bousarghin L, Bonnaure-Mallet M, Jolivet-Gougeon A (2015) Oral Gram-negative anaerobic bacilli as a reservoir of $\beta$-lactam resistance genes facilitating infections with multiresistant bacteria. Int J Antimicrob Agents 45, 99-105.

[148] Gosney M, Punekar S, Playfer JR, Bilsborrow PK, Martin MV (2003) The incidence of oral Gram-negative bacteria in patients with Parkinson's disease. Eur J Intern Med 14, 484-487.

[149] Chang Y-P, Yang C-J, Hu K-F, Chao A-C, Chang Y-H, Hsieh K-P, Tsai J-H, Ho P-S, Lim S-Y (2016) Risk factors for pneumonia among patients with Parkinson's disease: A Taiwan nationwide population-based study. Neuropsychiatr Dis Treat 12, 1037-1046.

[150] Pennington S, Snell K, Lee M, Walker R (2010) The cause of death in idiopathic Parkinson's disease. Parkinsonism Relat Disord 16, 434-437.

[151] Liu C, Cao Y, Lin J, Ng L, Needleman I, Walsh T, Li C (2018) Oral care measures for preventing nursing home-acquired pneumonia. Cochrane Database Syst Rev 9, CD012416.

[152] Satheeshkumar PS, Papatheodorou S, Sonis S (2020) Enhanced oral hygiene interventions as a risk mitigation strategy for the prevention of non-ventilator-associated pneumonia: A systematic review and meta-analysis. $\mathrm{Br}$ Dent J 228, 615-622.

[153] South AR, Somers SM, Jog MS (2010) Gum chewing improves swallow frequency and latency in Parkinson patients: A preliminary study. Neurology 74, 1198-1202.

[154] Brugger F, Erro R, Balint B, Kägi G, Barone P, Bhatia KP (2015) Why is there motor deterioration in Parkinson's disease during systemic infections-a hypothetical view. NPJ Parkinsons Dis 1, 15014.

[155] Adams B, Nunes JM, Page MJ, Roberts T, Carr J, Nell TA, Kell DB, Pretorius E (2019) Parkinson's disease: A systemic inflammatory disease accompanied by bacterial inflammagens. Front Aging Neurosci 11, 210.
[156] Kaur T, Uppoor A, Naik D (2016) Parkinson's disease and periodontitis - the missing link? A review. Gerodontology 33, 434-438.

[157] Madhav NVS, Shakya AK, Shakya P, Singh K (2009) Orotransmucosal drug delivery systems: A review. J Control Release 140, 2-11.

[158] Shakya P, Madhav NVS, Shakya AK, Singh K (2011) Palatal mucosa as a route for systemic drug delivery: A review. J Control Release 151, 2-9.

[159] Zhang H, Zhang J, Streisand JB (2002) Oral mucosal drug delivery: Clinical pharmacokinetics and therapeutic applications. Clin Pharmacokinet 41, 661-680.

[160] Rascol O, Azulay J-P, Blin O, Bonnet A-M, BrefelCourbon C, Césaro P, Damier P, Debilly B, Durif F, Galitzky M, Grouin J-M, Pennaforte S, Villafane G, Yaici S, Agid Y (2010) Orodispersible sublingual piribedil to abort OFF episodes: A single dose placebo-controlled, randomized, double-blind, cross-over study. Mov Disord 25, 368-376.

[161] Lai KL, Fang Y, Han H, Li Q, Zhang S, Li HY, Chow SF, Lam TN, Lee WYT (2018) Orally-dissolving film for sublingual and buccal delivery of ropinirole. Colloids Surf B Biointerfaces 163, 9-18.

[162] Gupta HV, Lyons KE, Pahwa R (2019) Old drugs, new delivery systems in Parkinson's disease. Drugs Aging 36, 807-821.

[163] Olanow CW, Factor SA, Espay AJ, Hauser RA, Shill HA, Isaacson S, Pahwa R, Leinonen M, Bhargava P, Sciarappa K, Navia B, Blum D, CTH-300 Study investigators (2020) Apomorphine sublingual film for off episodes in Parkinson's disease: A randomised, double-blind, placebocontrolled phase 3 study. Lancet Neurol 19, 135-144.

[164] Miller N, Noble E, Jones D, Deane KHO, Gibb C (2011) Survey of speech and language therapy provision for people with Parkinson's disease in the United Kingdom: Patients' and carers' perspectives. Int J Lang Commun Disord 46, 179-188.

[165] Sturrock A, Cussons H, Jones C, Woodcock C, Bird L (2017) Oral health promotion in the community pharmacy: An evaluation of a pilot oral health promotion intervention. Br Dent J 223, 521-525.

[166] Sturrock A, Preshaw PM, Hayes C, Wilkes S (2020) 'We do not seem to engage with dentists': A qualitative study of primary healthcare staff and patients in the North East of England on the role of pharmacists in oral healthcare. BMJ Open 10, e032261.

[167] Kaplan D (2000) Oral health, dental care and quality of life issues in Parkinson's disease. Loss Grief Care 8, 87-92.

[168] Csoti I, Jost WH, Reichmann H (2016) Parkinson's disease between internal medicine and neurology. J Neural Transm (Vienna) 123, 3-17.

[169] Hein C, Williams RC (2017) The impact of oral health on general health: Educating professionals and patients. Curr Oral Health Rep 4, 8-13.

[170] Berkowitz O, Brisotti MF, Gascon L, Henshaw M, Kaufman LB (2017) The impact of an interprofessional oral health curriculum on trainees. J Physician Assist Educ 28, 2-9.

[171] Kaufman LB, Soto A, Gascon L, Quintiliani L, Weinberg J, Joshi P, Chippendale R (2017) Oral health for older adults: An interprofessional workshop for medical students. MedEdPORTAL 13, 10572.

[172] Park SE, Donoff RB, Saldana F (2017) The impact of integrating oral health education into a medical curriculum. Med Princ Pract 26, 61-65. 
[173] Jeter CB, Rozas NS, Sadowsky JM, Jones DJ (2018) Parkinson's disease oral health module: Interprofessional coordination of care. MedEdPORTAL 14, 10699.

[174] Argolo N, Nóbrega AC (2013) Dysphagia complaint and gender in Parkinson's disease. Eur J Neurol 20, e42.

[175] Applebaum GM, Langsam BW, Huba G (1997) The implant retained UCLA-type clip bar overdenture. A solution to the mandibular edentulous patient affected by Parkinson's disease. Oral Health 87, 65-67, 69-70, 72.

[176] Arora R, Sharma RK, Tewari S, Kapoor H (2017) Periodontal surgery in a stage II Parkinson's disease patient: Report of a case with special considerations. World J Neurol 7, 24-27.

[177] Asif A, Meenakshi K, Vikas P, Saransh M (2017) Prosthodontic care for edentulous patients with Parkinson disease. Ann Essences Dent IX, 9b-13b.

[178] Herren C, Abadi B (2005) Urgent denture repair in a medically compromised patient. Gen Dent 53, 60-62.

[179] Singh Y, Saini M, Garg N (2013) Oral rehabilitation of a Parkinson's patient: A case report. World J Clin Cases 1, 67-70.

[180] De Visschere LM, Vanobbergen JN (2006) Oral health care for frail elderly people: Actual state and opinions of dentists towards a well-organised community approach. Gerodontology 23, 170-176.

[181] Henry RG, Ceridan B (1994) Delivering dental care to nursing home and homebound patients. Dent Clin North Am 38, 537-551.

[182] Longhurst RH (2002) Availability of domiciliary dental care for the elderly. Prim Dent Care 9, 147-150.

[183] Girestam Croonquist C, Dalum J, Skott P, Sjögren P, Wårdh I, Morén E (2020) Effects of domiciliary professional oral care for care-dependent elderly in nursing homes - oral hygiene, gingival bleeding, root caries and nursing staff's oral health knowledge and attitudes. Clin Interv Aging 15, 1305-1315.

[184] Barbe AG, Kottmann HE, Derman SHM, Noack MJ (2019) Efficacy of regular professional brushing by a dental nurse for 3 months in nursing home residents-A randomized, controlled clinical trial. Int J Dent Hyg 17, 327-335.

[185] Barbe AG, Küpeli LS, Hamacher S, Noack MJ (2020) Impact of regular professional toothbrushing on oral health, related quality of life, and nutritional and cognitive status in nursing home residents. Int J Dent Hyg $\mathbf{1 8}$, 238-250.

[186] Ranjan R, Abhinay A, Mishra M (2018) Can oral microbial infections be a risk factor for neurodegeneration? A review of the literature. Neurol India 66, 344-351.

[187] Kitamoto S, Nagao-Kitamoto H, Jiao Y, Gillilland MG, Hayashi A, Imai J, Sugihara K, Miyoshi M, Brazil JC, Kuffa P, Hill BD, Rizvi SM, Wen F, Bishu S, Inohara N, Eaton KA, Nusrat A, Lei YL, Giannobile WV, Kamada N (2020) The intermucosal connection between the mouth and gut in commensal pathobiont-driven colitis. Cell 182, 447-462.e14.

[188] Baizabal-Carvallo JF, Alonso-Juarez M (2020) The link between gut dysbiosis and neuroinflammation in Parkinson's disease. Neuroscience 432, 160-173.

[189] Fitzgerald E, Murphy S, Martinson HA (2019) Alphasynuclein pathology and the role of the microbiota in Parkinson's disease. Front Neurosci 13, 369.

[190] Sampson TR, Challis C, Jain N, Moiseyenko A, Ladinsky MS, Shastri GG, Thron T, Needham BD, Horvath I, Debelius JW, Janssen S, Knight R, Wittung-Stafshede P,
Gradinaru V, Chapman M, Mazmanian SK (2020) A gut bacterial amyloid promotes $\alpha$-synuclein aggregation and motor impairment in mice. Elife 9, e53111.

[191] Yang D, Zhao D, Ali Shah SZ, Wu W, Lai M, Zhang X, Li J, Guan Z, Zhao H, Li W, Gao H, Zhou X, Yang L (2019) The role of the gut microbiota in the pathogenesis of Parkinson's disease. Front Neurol 10, 1155.

[192] Sampson TR, Debelius JW, Thron T, Janssen S, Shastri GG, Ilhan ZE, Challis C, Schretter CE, Rocha S, Gradinaru V, Chesselet M-F, Keshavarzian A, Shannon KM, Krajmalnik-Brown R, Wittung-Stafshede P, Knight R, Mazmanian SK (2016) Gut microbiota regulate motor deficits and neuroinflammation in a model of Parkinson's disease. Cell 167, 1469-1480.e12.

[193] Maini Rekdal V, Bess EN, Bisanz JE, Turnbaugh PJ, Balskus EP (2019) Discovery and inhibition of an interspecies gut bacterial pathway for Levodopa metabolism. Science 364, eaau6323.

[194] Nyholm D, Hellström PM (2021) Effects of Helicobacter pylori on levodopa pharmacokinetics. J Parkinsons Dis 11, 61-69.

[195] van Kessel SP, Frye AK, El-Gendy AO, Castejon M, Keshavarzian A, van Dijk G, El Aidy S (2019) Gut bacterial tyrosine decarboxylases restrict levels of levodopa in the treatment of Parkinson's disease. Nat Commun 10, 310 .

[196] van Kessel SP, de Jong HR, Winkel SL, van Leeuwen SS, Nelemans SA, Permentier H, Keshavarzian A, El Aidy S (2020) Gut bacterial deamination of residual levodopa medication for Parkinson's disease. BMC Biology 18, 137.

[197] Jolivet-Gougeon A, Bonnaure-Mallet M (2018) Treponema, iron and neurodegeneration. Curr Alzheimer Res 15, 716-722.

[198] Olsen I, Kell DB, Pretorius E (2020) Is Porphyromonas gingivalis involved in Parkinson's disease? Eur J Clin Microbiol Infect Dis 39, 2013-2018.

[199] Chen C-K, Wu Y-T, Chang Y-C (2017) Periodontal inflammatory disease is associated with the risk of Parkinson's disease: A population-based retrospective matched-cohort study. PeerJ 5, e3647.

[200] Hsu Y-C, Chang C-W, Lee H-L, Chuang C-C, Chiu HC, Li W-Y, Horng J-T, Fu E (2016) Association between history of dental amalgam fillings and risk of Parkinson's disease: A population-based retrospective cohort study in Taiwan. PLoS One 11, e0166552.

[201] Liu T-C, Sheu J-J, Lin H-C, Jensen DA (2013) Increased risk of parkinsonism following chronic periodontitis: A retrospective cohort study. Mov Disord 28, 1307-1308.

[202] Chen C-K, Huang J-Y, Wu Y-T, Chang Y-C (2018) Dental scaling decreases the risk of Parkinson's disease: A nationwide population-based nested case-control study. Int J Environ Res Public Health 15, 1587.

[203] Patrick KL, Bell SL, Weindel CG, Watson RO (2019) Exploring the "multiple-hit hypothesis" of neurodegenerative disease: Bacterial infection comes up to bat. Front Cell Infect Microbiol 9, 138.

[204] Belstrøm D (2020) The salivary microbiota in health and disease. J Oral Microbiol 12, 1723975.

[205] Woo HG, Chang Y, Lee JS, Song T-J (2020) Association of tooth loss with new-onset Parkinson's disease: A nationwide population-based cohort study. Parkinsons Dis $\mathbf{2 0 2 0}$, 4760512.

[206] Dixit A, Mehta R, Singh AK (2019) Proteomics in human Parkinson's disease: Present scenario and future directions. Cell Mol Neurobiol 39, 901-915. 
[207] Farah R, Haraty H, Salame Z, Fares Y, Ojcius DM, Said Sadier N (2018) Salivary biomarkers for the diagnosis and monitoring of neurological diseases. Biomed J 41, 63-87.

[208] Bougea A, Koros C, Stefanis L (2019) Salivary alphasynuclein as a biomarker for Parkinson's disease: A systematic review. J Neural Transm (Vienna) 126, 13731382.

[209] Chen Y, Zheng J, Su L, Chen F, Zhu R, Chen X, Ye Q (2020) Increased salivary microRNAs that regulate DJ1 gene expression as potential markers for Parkinson's disease. Front Aging Neurosci 12, 210.

[210] Cressatti M, Juwara L, Galindez JM, Velly AM, Nkurunziza ES, Marier S, Canie O, Gornistky M, Schipper HM (2020) Salivary microR-153 and microR-223 Levels as Potential Diagnostic Biomarkers of Idiopathic Parkinson's Disease. Mov Disord 35, 468-477.

[211] Masters JM, Bestwick J, Warner TT, Giovannoni G, Proctor GB, Noyce AJ (2015) Systematic review and metaanalysis of salivary protein concentration in Parkinson's disease. Mov Disord 30, 1971-1972.

[212] Vivacqua G, Suppa A, Mancinelli R, Belvisi D, Fabbrini A, Costanzo M, Formica A, Onori P, Fabbrini G, Berardelli A (2019) Salivary alpha-synuclein in the diagnosis of Parkinson's disease and progressive supranuclear palsy. Parkinsonism Relat Disord 63, 143-148.

[213] Schröder JB, Marian T, Claus I, Muhle P, Pawlowski M, Wiendl H, Suntrup-Krueger S, Meuth SG, Dziewas R, Ruck T, Warnecke T (2019) Substance P saliva reduction predicts pharyngeal dysphagia in Parkinson's disease. Front Neurol 10, 386.

[214] Adler CH, Serrano GE, Zhang N, Hinni ML, Lott DG, Mehta SH, Sue LI, Intorcia A, Beach TG (2019) Feasibility of repeat and bilateral submandibular gland needle biopsies in Parkinson's disease. Parkinsonism Relat Disord 68, 69-72.

[215] Manne S, Kondru N, Jin H, Anantharam V, Huang X, Kanthasamy A, Kanthasamy AG (2020) $\alpha$-Synuclein real-time quaking-induced conversion in the submandibular glands of Parkinson's disease patients. Mov Disord 35, 268-278.

[216] Shin J, Park S-H, Shin C, Kim J-H, Yun TJ, Kim H-J, Jeon B (2019) Submandibular gland is a suitable site for alpha synuclein pathology in Parkinson disease. Parkinsonism Relat Disord 58, 35-39.

[217] Besnard P, Christensen JE, Bernard A, Simoneau-Robin I, Collet X, Verges B, Burcelin R (2020) Identification of an oral microbiota signature associated with an impaired orosensory perception of lipids in insulinresistant patients. Acta Diabetol 57, 1445-1451.

[218] Gruffaz M, Zhang T, Marshall V, Gonçalves P, Ramaswami R, Labo N, Whitby D, Uldrick TS, Yarchoan R, Huang Y, Gao S-J (2020) Signatures of oral microbiome in HIV-infected individuals with oral Kaposi's sarcoma and cell-associated KSHV DNA. PLOS Pathogens 16, e1008114.

[219] Singh H, Torralba MG, Moncera KJ, DiLello L, Petrini J, Nelson KE, Pieper R (2019) Gastro-intestinal and oral microbiome signatures associated with healthy aging. GeroScience 41, 907-921.

[220] Yang S-F, Huang H-D, Fan W-L, Jong Y-J, Chen M-K, Huang C-N, Chuang C-Y, Kuo Y-L, Chung W-H, Su SC (2018) Compositional and functional variations of oral microbiota associated with the mutational changes in oral cancer. Oral Oncology 77, 1-8.

[221] Bell JS, Spencer JI, Yates RL, Yee SA, Jacobs BM, DeLuca GC (2019) Invited Review: From nose to gut - the role of the microbiome in neurological disease. Neuropathol Appl Neurobiol 45, 195-215.

[222] Heintz-Buschart A, Pandey U, Wicke T, Sixel-Döring F, Janzen A, Sittig-Wiegand E, Trenkwalder C, Oertel WH, Mollenhauer B, Wilmes P (2018) The nasal and gut microbiome in Parkinson's disease and idiopathic rapid eye movement sleep behavior disorder. Mov Disord 33, 88-98.

[223] Kato T, Yamazaki K, Nakajima M, Date Y, Kikuchi J, Hase K, Ohno H, Yamazaki K (2018) Oral administration of Porphyromonas gingivalis alters the gut microbiome and serum metabolome. mSphere 3, e00460-18.

[224] Frota BMD, Holanda SN, Sousa FB, Alves APNN, Frota BMD, Holanda SN, Sousa FB, Alves APNN (2016) Evaluation of oral conditions in patients with neurodegenerative diseases treated in geriatric centers. Rev Gaúch Odontol 64, 17-23.

[225] Tiisanoja A, Syrjälä A-M, Komulainen K, Lampela P, Hartikainen S, Taipale H, Knuuttila M, Ylöstalo P (2018) Anticholinergic burden and dry mouth among Finnish, community-dwelling older adults. Gerodontology 35, 3-10.

[226] Ali GN, Wallace KL, Schwartz R, DeCarle DJ, Zagami AS, Cook IJ (1996) Mechanisms of oral-pharyngeal dysphagia in patients with Parkinson's disease. Gastroenterology 110, 383-392.

[227] Liu F-C, Su W-C, You C-H, Wu AY-J (2015) All-on4 concept implantation for mandibular rehabilitation of an edentulous patient with Parkinson disease: A clinical report. J Prosthet Dent 114, 745-750.

[228] Mu L, Sobotka S, Chen J, Su H, Sanders I, Adler CH, Shill HA, Caviness JN, Samanta JE, Beach TG, Arizona Parkinson's Disease Consortium (2012) Altered pharyngeal muscles in Parkinson disease. J Neuropathol Exp Neurol 71, 520-530.

[229] Nicaretta DH, Rosso AL, Mattos JP de, Maliska C, Costa MMB (2013) Dysphagia and sialorrhea: The relationship to Parkinson's disease. Arq Gastroenterol 50, 42-49.

[230] Rascol O, Negre-Pages L, Damier P, Delval A, Derkinderen P, Destée A, Fabbri M, Meissner WG, Rachdi A, Tison F, Perez-Lloret S, COPARK Study Group (2020) Excessive buccal saliva in patients with Parkinson's disease of the French COPARK cohort. J Neural Transm (Vienna) 127, 1607-1617.

[231] Atkinson-Clement C, Sadat J, Pinto S (2015) Behavioral treatments for speech in Parkinson's disease: Metaanalyses and review of the literature. Neurodegener Dis Manag 5, 233-248.

[232] Dashtipour K, Tafreshi A, Lee J, Crawley B (2018) Speech disorders in Parkinson's disease: Pathophysiology, medical management and surgical approaches. Neurodegener Dis Manag 8, 337-348.

[233] Barbe AG, Heinzler A, Derman S, Hellmich M, Timmermann L, Noack MJ (2017) Hyposalivation and xerostomia among Parkinson's disease patients and its impact on quality of life. Oral Dis 23, 464-470.

[234] Makzoume JE (2008) Complete denture prosthodontics for a patient with Parkinson's disease using the neutral zone concept: A clinical report. Gen Dent 56, e12-16.

[235] Arbouw MEL, Movig KLL, Koopmann M, Poels PJE, Guchelaar H-J, Egberts TCG, Neef C, van Vugt JPP (2010) Glycopyrrolate for sialorrhea in Parkinson disease: A randomized, double-blind, crossover trial. Neurology 74, 1203-1207. 
[236] Bloem BR, Kalf JG, van de Kerkhof PCM, Zwarts MJ (2009) Debilitating consequences of drooling. J Neurol 256, 1382-1383.

[237] Kalf JG, Bloem BR, Munneke M (2012) Diurnal and nocturnal drooling in Parkinson's disease. J Neurol 259, 119-123.

[238] Morgante F, Bavikatte G, Anwar F, Mohamed B (2019) The burden of sialorrhoea in chronic neurological conditions: Current treatment options and the role of incobotulinumtoxinA (Xeomin $\left.{ }^{\circledR}\right)$. Ther Adv Neurol Disord 12, 1756286419888601.

[239] Varley LP, Denieffe S, O'Gorman C, Murphy A, Gooney M (2019) A systematic review of noninvasive and invasive sialorrhoea management. J Clin Nurs 28, 4190-4206.

[240] de Baat C, Verhoeff M, Ahlberg J, Manfredini D, Winocur E, Zweers P, Rozema F, Vissink A, Lobbezoo F (2021) Medications and addictive substances potentially inducing or attenuating sleep bruxism and/or awake bruxism. J Oral Rehabil 48, 343-354.

[241] Packer ME (2015) Are dental implants the answer to tooth loss in patients with Parkinson's disease? Prim Dent J 4, $35-41$.

[242] Brailsford SR, Fiske J, Gilbert S, Clark D, Beighton D (2002) The effects of the combination of chlorhexidine/ thymol- and fluoride-containing varnishes on the severity of root caries lesions in frail institutionalised elderly people. J Dent 30, 319-324.

[243] Clifford TJ, Warsi MJ, Burnett CA, Lamey PJ (1998) Burning mouth in Parkinson's disease sufferers. Gerodontology 15, 73-78.

[244] Koszewicz M, Mendak M, Konopka T, KoziorowskaGawron E, Budrewicz S (2012) The characteristics of autonomic nervous system disorders in burning mouth syndrome and Parkinson disease. J Orofac Pain 26, 315-320.

[245] Cerajewska TL, West NX (2019) Dementia friendly dentistry for the periodontal patient. Part 1: Recognising and assessing patients with dementia. Br Dent $J$ 227, 563-569.

[246] Cerajewska TL, West NX (2019) Dementia friendly dentistry for the periodontal patient. Part 2: Ethical treatment planning and management. Br Dent J 227, 570-576.

[247] Chen K, Ye M, Shen X (2017) Anesthetic management for retrieval of a large aspirated denture in a patient with Parkinson's disease. J Clin Anesth 43, 59-60.

[248] Sacks OW, Ross SJ, DePaola DP, Kohl MS (1970) Abnormal mouth-movements and oral damage associated with L-DOPA treatment. Ann Dent 29, 130-144. 